\title{
Conflict Journalism through the Practice of Embedded
}

\section{Reporting}

\author{
by \\ Thamar Spitzer
}

A thesis submitted to the Faculty of Graduate and Postdoctoral Affairs in partial fulfillment of the requirements for the degree of

Master of Journalism

in

Master of Journalism Studies

Carleton University

Ottawa, Ontario

(C) 2021, Thamar Spitzer 


\begin{abstract}
With a Canadian focus wherever possible, this thesis explores the history of conflict coverage and evaluates the common criticism of North American modern conflict coverage by practice of embedded journalism. The thesis is intended to shine a light on the issue for news consumers and advocate for greater transparency in conflict journalism but does not attempt to make recommendations for military embedding programs. Rather, this thesis suggests a new way to look at embedded journalism in its next iteration to better understand the impact of the journalism, generated by embedded reporting, on news consumers. In assessing the efficacy of different methods of covering conflict, more attention could be devoted to the needs and reactions of journalistic audiences.
\end{abstract}




\section{Acknowledgements}

I would like to express gratitude to Allan Thompson, my Thesis Supervisor and Associate Director of the School of Journalism and Communication. I would also like to thank my Graduate Supervisor, Janice Tibbetts, who supported every venture and opportunity that came my way since beginning my bachelor's degree. Furthermore, I would like to extend a deep appreciation for Wendy Sewell, mentor, and role model. I thank Robert Bergen, for without, I would never have fallen on the subject of military journalism. I wish to acknowledge the help provided by the MacOdrum Library, their subject and research specialists. Finally, I wish to extend a special thank you to the family, friends, and mentors who have provided tremendous support throughout the past years. 


\section{Table of Contents}

Conflict Journalism through the Practice of Embedded Reporting ........................................i

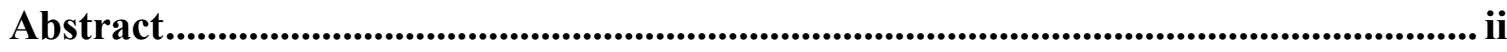

Acknowledgements ........................................................................................................ iii

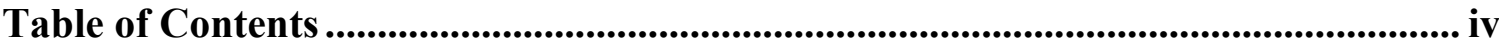

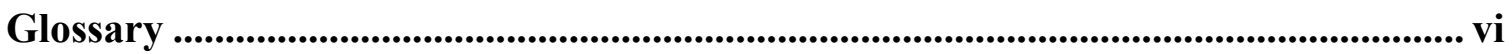

Chapter 1: History of conflict journalism and war reporting .................................... 7

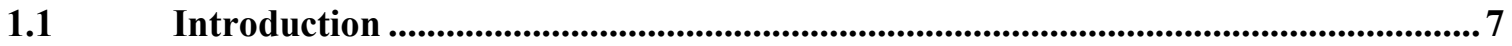

1.2 The Peloponnesian War (431 BCE-404 BCE)........................................................... 11

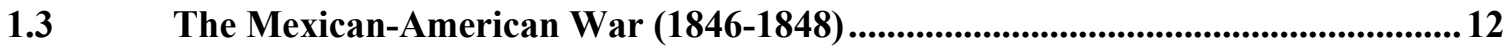

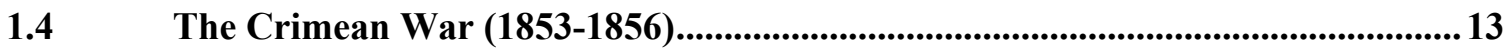

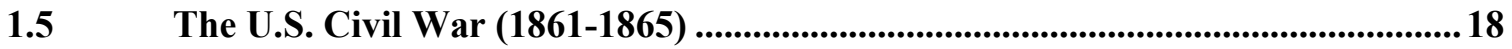

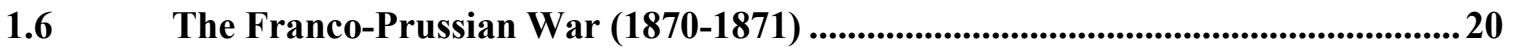

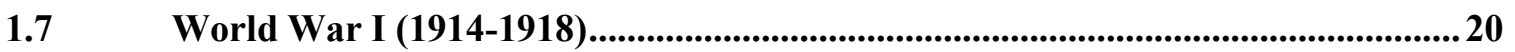

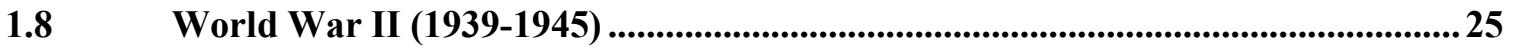

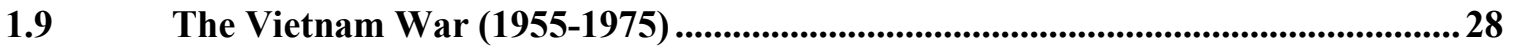

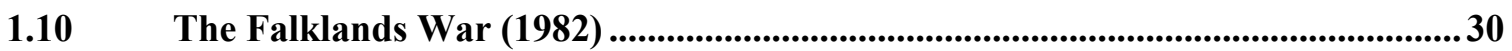

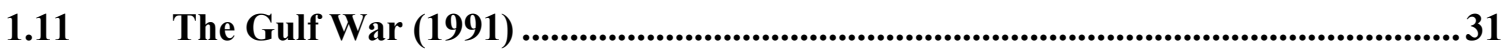

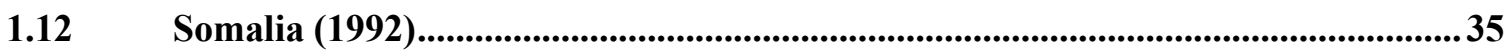

$1.13 \quad$ Bosnia (1995) and Kosovo (1999) ..............................................................................39

1.14 The US War in Afghanistan (2001-2020) ..............................................................

1.15 The Iraq War (2003-2011) ..........................................................................................42

$1.16 \quad$ Canada and the Afghanistan War (2001-2014) ............................................................48

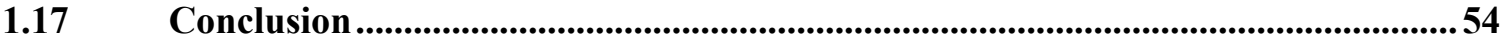


Chapter 2: Evaluating Modern Day Embedding Programs and the Content they

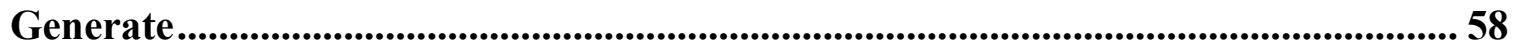

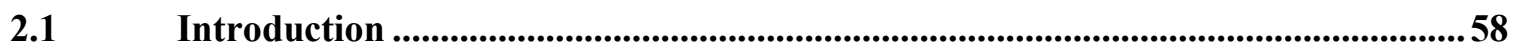

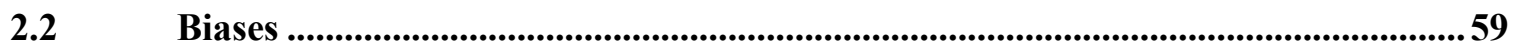

Traditional and Pragmatic Objectivity ..........................................................63

The Ability of Embedded Journalists to Relay the Truth....................................69

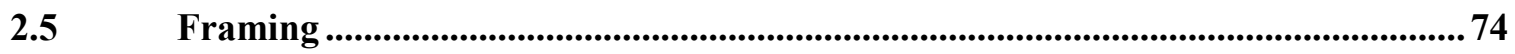

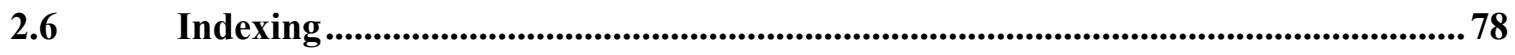

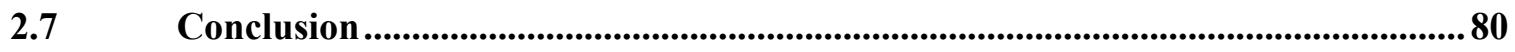

Chapter 3: Working Towards a New Understanding of Embedded Journalism .... 82

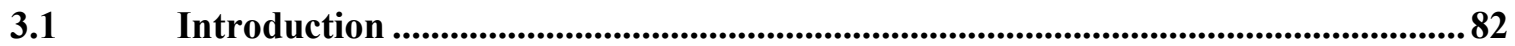

3.2 Democratic value of good conflict journalism and the Public Reliance on Good

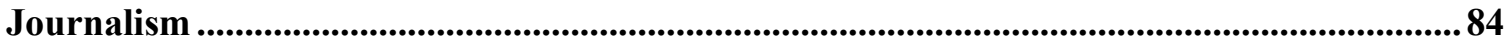

The Public Perception of Embedded Journalism ....................................................86

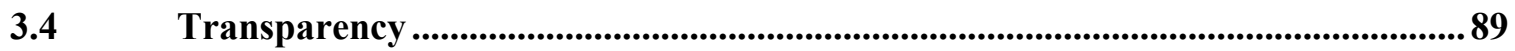

3.5 Moving beyond Common Criticism of Embedded Reporting................................92

3.6 Designing a Qualitative Interaction Analysis................ Error! Bookmark not defined.

Conclusion .............................................................................................................................994

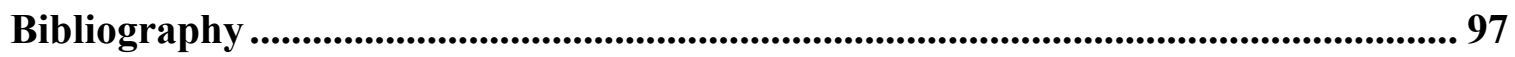




\section{Glossary}

BEF: British Expeditionary Forces

CAF: Canadian Armed Forces

CBC: Canadian Broadcasting Corporation

CBS: Columbia Broadcasting System

CEF: Canadian Expeditionary Forces

CF: Canadian Forces

CFMEP: Canadian Forces Media Embedding Program

CNN: Cable News Network

DND: Department of National Defence

DoD: Department of Defense (US)

FOB: Forward Operating Base

ISAF: International Security Assistance Force

JTF2: Canada's Joint Task Force 2

KAF: Kandahar Airfield

MOD: British Ministry of Defence

NATO: North Atlantic Treaty Organization

OFI: Operation Iraqi Freedom

OPSEC/ Operational/ Operations Security: Operational Security

RCN: Royal Canadian Navy

PAO: Public Affairs Officer

PPCLI: Princess Patricia's Canadian Light Infantry

PR: Public Relations

UN: United Nations

UNSC: United Nations Security Council

US: United States

USAF: United States Armed Forces

WMD: Weapons of Mass Destruction

WWI: World War One

WWII: World War Two 


\section{Chapter 1: History of conflict journalism and war reporting}

In short, the military will control press coverage as it deems necessary or convenient by applying the exceptions and restrictions, and the press will make no serious effort to overcome that by changing its ways. The loser on all counts is the public -Phillip Knightley. ${ }^{1}$

\subsection{Introduction}

Embedded reporters can gain a level of access to the war front that they would not otherwise be able to safely attain on their own. Since the inception of formalized embedding programs at the beginning of the 21 st century, war correspondents have received official protection from the military and previously unprecedented access to the front lines of battle. In some respects, the privileged access allowed for a standard of openness and immediacy in the journalism that informs the public of military deployment in foreign wars. But there is a trade-off. From the media's perspective, there have always been questions about how a journalist who eats, sleeps and travels with the hosting defence institution can effectively cover a conflict.

For a better understanding of embedded journalism, it is essential to review key developments in wartime coverage. Accordingly, this section attempts to briefly trace the history of war correspondence with specific attention to reporting conventions and technological advances to appreciate how journalistic practises, norms and values progressed into the way in which the public views journalism and how it is practised today. The technological advances, also referred to as the "digital shift," refer to the

\footnotetext{
${ }^{1}$ Knightley, The First Casualty : From the Crimea to Vietnam : The War Correspondent as Hero, Propagandist, and Myth Maker, 158.
} 
opportunities that different media modalities (text, photo, audio, video, and other emerging platforms) give way to new opportunities in recounting and explaining happenings to journalistic audiences. ${ }^{2}$

Frequently drawn from, is the seminal work of Phillip Knightley, The First Casualty: The War Correspondent as hero and myth-maker from the Crimea to Kosovo (2004) and the work of William V. Kennedy, The Military and the Media: why the press cannot be trusted to cover a war (1993). The title of Knightley's book makes reference to the British historian Arthur Ponsonby, who in 1928 famously "stated, "when war is declared, truth is the first casualty." ${ }^{3}$ Additionally, the most recent and comprehensive perspective is found in Sherry Wasilow's, Contemporary Canadian Military/Media relations: Embedded reporting during the Afghanistan War (2017). While a deep dive into the history of war correspondence might be compelling, it lays beyond the scope of this thesis.

This thesis focuses on North American war correspondence, particularly the embedding system used by the Canadian Forces (CF), the journalistic norms it employs, and paradigms in which it functions. Both were developed in a global context. To fully envisage war journalism, it is necessary to look at the picture as a whole in its

\footnotetext{
2 Jacobson, "Transcoding the News: An Investigation into Multimedia Journalism Published on Nytimes.Com 2000-2008."

${ }^{3}$ Ponsonby, Falsehood in War-Time, Containing an Assortment of Lies Circulated Throughout the Nations During the Great War, 11.
} 
development over time rather than bound to a specific geography. Structurally, the focus is on the Western world and English-language journalism.

The number of journalists covering wars and conflicts grew exponentially with the advent of modern communication technology and the increase of literacy in the western world. During the American Civil War, there were close to 600 war correspondents. In the Korean War, there were 1,600 correspondents and by the time of the Vietnam War, it is estimated that the number of accredited war correspondents was close to 5,000. For this reason alone, this research exercise is selective and aims to identify trends and capture snapshots of the environment that define the qualities of conflict journalism which emerged in the time it was produced. In the interest of brevity, certain wars and conflicts have been omitted, not because they do not have political importance or a devastating human toll, or because it would be banal to dissect the associated journalism. They are omitted because they did not radically alter the standard of conflict journalism. While this chapter does identify some notable war correspondents, the practice was largely an anonymous one until the $20^{\text {th }}$ century. Prior to that, bylines were uncommon and, if used, were clever initials or pseudonyms. ${ }^{4}$ Therefore it is difficult to identify the names of the earliest contributors to conflict journalism. There is an equal disarrange in the literature about who was the first war correspondent. For this thesis, Thucydides is identified as it is the oldest known, in-depth reporter of war. As for the first modern war correspondents, two journalists are

\footnotetext{
${ }^{4}$ Roth, Historical Dictionary of War Journalism.
} 
identified - George Wilkins Kendal, in the Mexican-American War (1846-1848) and Sir William Howard Russell, covering the Crimean War (1853-1856).

This chapter is a chronological recounting of conflict journalism paralleled with an examination of the progression in the standards and norms of journalism. What is most valuable in this section is in the recognition of the changing nature of military-media relationships and how the lessons learned by the militaries, most notably beginning in the Crimean war, affected information management in each consecutive conflict. In unravelling media-military relations, it becomes possible to understand why and how the Canadian Forces Media Embedding Program (CFMEP) stands in its current form. It is furthermore worth noting how various militaries and governments have skillfully adapted policy to censor and control journalists to officiate public opinion. A common pattern is of the efforts by journalists to use proximity to the military and conflict zones to generate coverage that will properly inform audiences being thwarted again and again by a military preoccupation with control of information, framing and outright censorship.

While the first large-scale embedding program officially — that is, written into policy — came into place in 2003, during the Iraq War (2003-2011) and in 2006 for Canada, during the Afghanistan War (2000-2014), the history of journalists on the front line goes much further back. The earliest known practice of wartime reporting or at least of historical writing about war, based on the use of some reporting techniques, dates to the Peloponnesian War (431 BCE- 404 BCE), where the city-states of Athens and Sparta fought in the last years of the golden age of ancient Greece. 


\subsection{The Peloponnesian War (431 BCE-404 BCE)}

Far predating professional journalism, the ancient Greek historian Thucydides ( 460 BCE- $400 \mathrm{BCE})$ is considered to be one of the first known conflict journalists. Thucydides, coming from the Athenian empire with the belief that there would be "a great war,"5 began documenting battles, their locations, names of deceased and their commanders. Nearly 2,500 years later, his 500-page scholarly text, now called History of the Peloponnesian War, continues to be analyzed. "Thucydides provides a sound basis from which to discover how best to approach the complex problems facing contemporary strategists by allowing us to better understand war's continuities and discontinuities." Travelling while collecting details of the war, as it happens, as opposed to the history told by recollection, Thucydides' work is known for developing the modern historical method. Using evidence-based thinking and scientific rigour, Thucydides distanced himself from emotion, storytelling and poetry, full of mysterious themes and prose, which often attributed events as the will of gods and esoteric forces. Rather he focused on omitting bias and sensationalism. It is the attempt to remove arbitrary expressions of opinions that makes Thucydides' work resemble the journalistic element of impartiality. ${ }^{7}$

Although little is known of Thucydides' life, his writing indicates that he had once been an Athenian general but was exiled after losing a major battle to the Spartans.

\footnotetext{
${ }^{5}$ Thucydides and Finley, Complete Writings of Thucydides : The Peloponnesian War.

${ }^{6}$ Gilchrist, "Why Thucydides Still Matters."

${ }^{7}$ Pearson, "Thucydides as Reporter and Critic."
} 
While being a combatant in a war set him aside from the modern war journalist, his exile forced him to travel much of the Athenian world, spending almost half of the 27-year war on the Spartan confederacy. The independence from faction does not disqualify a point of view. Rather it is a question of allegiance. ${ }^{8}$ Thucydides was unable to participate in partisan politics by nature of his exile, holding fidelity to accuracy and choosing facts over opinion. It is thus here where we see the emergence of war correspondence and using journalism to collect and record history.

\subsection{The Mexican-American War (1846-1848)}

Called the birth of the modern war correspondent, ${ }^{9}$ the Mexican-American War saw as many as ten correspondents that were employed in several southern newspapers (New Orleans Delta, New Orleans Picayune, the Delta, and the Jefferson Inquirer). The "printers," as they were called at the time, were attached to military companies because most able-bodied men had enlisted in the war. The most well-known correspondent from this time was George Wilkins Kendall, the co-founder of the New Orleans Picayune in 1837. There is also evidence of the first female war correspondents, Jane McManus Storms, who wrote under the byline pseudonyms "Cora Montgomery," "Montgomery," Jane Storm," or "Jane Cazneau" for the penny press newspaper the New York Sun. Storms

\footnotetext{
${ }^{8}$ Kovach and Rosenstiel, The Elements of Journalism: What Newspeople Should Know and the Public Should Expect.

${ }^{9}$ Roth, Historical Dictionary of War Journalism.
} 
was the only reporter to get behind the Mexican lines and one of several who criticized other journalists' critical ability in covering the war as well as the American forces. ${ }^{10}$

The Mexican-American war was equally significant for war reporting because, although their identities remain unknown, it was the first war covered by wartime photographers, using the daguerreotype process. ${ }^{11}$ The daguerreotypes had an exposure time of a minute and were thus not useful in covering action - and accordingly not highly employed — but it is the first time the modality of photographs was used in conflict reporting.

\subsection{The Crimean War (1853-1856)}

In Britain, The Times had been covering the Crimean War through mail correspondence by letters that were sent by local Crimean people as well as those from the British military until the demand for information grew so widely that the conventional method was reorganized. By having a journalist on the frontline, war coverage was remodelled into reportage that could independently scrutinize the British Army. Sir William Howard Russell is widely regarded as the first modern war reporter marking the onset of conflict coverage to a civilian population through the use of a civilian reporter. ${ }^{12}$ In some ways, he is also the first embedded reporter, camping with the British troops.

\footnotetext{
${ }^{10}$ Roth; Griffin, "Jane McManus Storm Cazneau, 1807-1878."

${ }^{11}$ Roth, Historical Dictionary of War Journalism, 202.

${ }^{12}$ Henrichsen and M. Lisosky, War on Words: Who Should Protect Journalists?, 13.
} 
In his career, Russell covered the Schleswig-Holstein and Denmark conflict, the Crimean War, the Indian Mutiny, the American Civil War, the Austro-Prussian War, the Franco-Prussian War, the Paris Commune, and the Zulu War of 1879. Although the new communicational procedure set structures that could separate journalists from the military establishments, journalists were compelled by a sense of patriotism to romanticize what they saw.

Spending more than 22 months in Crimea, writing for The Times as a 'special correspondent,' Russell is considered to be a trailblazer by virtue of his position as an observer and an agent of the public rather than a participant. Among his dispatches was the first time the public read about the gruesome reality of the Crimean War. His dispatches developed into the 19-century reporting model, ${ }^{13}$ which increasingly relied on the use of what was termed 'special correspondents'-journalists who travelled internationally to be close to the front lines of war. "[H]is war reporting was considerably closer to the truth than anything the public had previously been permitted to learn, and his influence on the conduct of the Crimean was immense."14

Witnessing the British military's heavy devastation in the Battle of Balaclava (1854), Russell provided a citizen's account and watched as the British cavalry charged into the "Valley of Death." In his article published on November 14, 1854, he wrote, "Our Light Brigade was annihilated by their own rashness, and by the brutality of a

\footnotetext{
${ }^{13}$ Rodgers, Reporting Conflict, 9-10.

${ }^{14}$ Knightley, The First Casualty : From the Crimea to Vietnam : The War Correspondent as Hero, Propagandist, and Myth Maker, 3.
} 
ferocious enemy." In later weeks, the manoeuvre was memorialized by Alfred Tennyson's narrative poem, The Charge of Light Calvary Brigade, failed and resulted in high British casualties. Russell's writing was so compelling that Florence Nightingale headed east and would come to prominence as the founder of modern nursing while serving during the Crimean War. Russell's reports played a significant role in the success of the Siege of Sevastopol.

Russell's war reporting is of significance because his pieces were met with high public response. The mass media provided a way for the public to interact with the war, dubbing the Crimean War "the people's war" and functioning to expand public interaction and expanded the conversation in the Habermasian political public sphere ${ }^{15}$ through letters to the editor sections in the newspapers. Almost 50 years after the war, Edwin Godkin of the Daily News wrote: "I cannot help thinking that the appearance of the special correspondent in the Crimea...led to a real awakening ...It brought home to the [government] the fact that the public had something to say about the conduct of wars and that they are not the concern exclusively of sovereigns and statesmen."16

The Crimean War was the first war that fulfilled the element of journalism that relates to providing a forum for public criticism and compromise ${ }^{17}$ In the London Times, Russell exposed the gross negligence and incompetence of the British high command. "It

\footnotetext{
${ }^{15}$ Markovits, "Rushing into Print: 'Participatory Journalism' during the Crimean War."

${ }^{16}$ Knightley, The First Casualty : From the Crimea to Vietnam : The War Correspondent as Hero, Propagandist, and Myth Maker, 17.

${ }^{17}$ Kovach and Rosenstiel, The Elements of Journalism : What Newspeople Should Know and the Public Should Expect.
} 
was clear that before the war ended the army realised it had made a mistake in tolerating Russell...but by then it was too late."18

After passage of a bill to investigate the Battle of Balaclava, the British public reaction was so strong that the standing government of George Hamilton-Gordon, 4th Earl of Aberdeen, fell in a vote of no confidence. ${ }^{19}$ The subsequent commander-in-chief, Sir William Codrington, issued a general order in 1856, which: "[F] orbade the publication of details of value to the enemy, authorised the ejection of a correspondent who, it was alleged, had published such details, and threatened future offenders with the same punishment." ${ }^{20}$ Knightly regards this moment as the origin of military censorship, setting a precedent for the wars to come.

In the history of embedding, Russell's work — and the reaction to it — carries a lot of weight as it can be seen as the first real "confrontation" between the military and the media. As the war went on, the press felt it was less important to affirm the military values of patriotism and policies of non disclosure. ${ }^{21}$ This came with high debate, and the beginnings of full censorship and limitations on the military were put into place. "He [William Howard Russell] proved that an unfettered journalist is a burden to the military in the field, anathema to a government at home, but essential to a free society."22

\footnotetext{
${ }^{18}$ Knightley, The First Casualty : From the Crimea to Vietnam : The War Correspondent as Hero, Propagandist, and Myth Maker, 17.

${ }^{19}$ Mathews, "THE FATHER OF WAR CORRESPONDENTS."

${ }^{20}$ Knightley, The First Casualty : From the Crimea to Vietnam : The War Correspondent as Hero, Propagandist, and Myth Maker, 16.

${ }^{21}$ Baker, "The Crimean War and the Freedom of the Press."

22 Anam Khan, "The Media and the Military."
} 
In the English language press, this begins the anathema of a relationship between the military and the media, a conflict over press access to information and access on the war front. A quotation that is frequently revisited in this thesis comes to mind. Author of the first military-media relations book, William V. Kennedy, The Military and the Media: Why the Press Cannot Be Trusted to Cover a War writes; "In short, the military will control press coverage as it deems necessary or convenient by applying the exceptions and restrictions, and the press will make no serious effort to overcome that by changing its ways. The loser on all counts is the public."23 The British coverage of the Crimean War begins the pattern of the efforts by journalists to use proximity to the military and conflict zones to generate coverage that will properly inform audiences, being thwarted again and again by a military preoccupation with control of information, framing and outright censorship.

The main criticisms of the journalism that was produced at the time are visible in Russell's work. Historians write that Russell failed to reveal and understand the greater causes of war $^{24}$ through a contemporary lens. Russell put together his own sort of British military uniform, which might visibly suggest he served as an arm of the British military. His impartiality is also brought into question for the use of first-person pronouns such as "I," "we," and "our," 25 indicating little or no distance between the journalist and the

\footnotetext{
${ }^{23}$ Kennedy, The Military and the Media: Why the Press Cannot Be Trusted to Cover a War, 31:158.

${ }^{24}$ Knightley, The First Casualty: From the Crimea to Vietnam : The War Correspondent as Hero, Propagandist, and Myth Maker, 15.

${ }^{25}$ Rodgers, Reporting Conflict .
} 
story. It has been suggested that the use of first-person pronouns, ${ }^{26}$ what was once typical in proto-embedded reporting, may contribute to the persuasiveness ${ }^{27}$ or influence of the journalism. As shown in Russell's journalism, the expression of opinions formed by journalistic audiences can lead to political action in active ways (discussing, voting) and passive ways (contemplation, interest). ${ }^{28}$

\subsection{The U.S. Civil War (1861-1865)}

Technological advancements allowed for the large-scale usage of the telegraph, making it the most extensive and timely coverage to date. ${ }^{29}$ In 1861 , the first transcontinental telegraph line was complete and provided for the first high-speed connection. At the onset of the American Civil War, the distance covered by the telegraph line exceeded the length of the railroad coverage, with-although presumed inflated $^{30} \_50,000$ miles of line $(80,467 \mathrm{~km})$. The byline, "By telegraph," was in frequent use as the demand for news coverage grew extensively, bringing in considerable revenue for the mass press. The conflict was not only extensively covered by the 500 journalists sent off to report in the North, and about 100 in the South, but European press arranged for coverage, sending correspondents such as Russell of The Times.

\footnotetext{
${ }^{26}$ Gerbner, "Persian Gulf War, The Movie."

${ }^{27}$ Dafouz-Milne, "The Pragmatic Role of Textual and Interpersonal Metadiscourse Markers in the Construction and Attainment of Persuasion: A Cross-Linguistic Study of Newspaper Discourse."

${ }^{28}$ Child and Casper, "Embedded Reporting and Audience Responce in the Iraq War"; Price, "Social Identification and Public Opinion: Effects of Communicating Group Conflict."

${ }^{29}$ Knightley, The First Casualty : From the Crimea to Vietnam : The War Correspondent as Hero, Propagandist, and Myth Maker, 19.

${ }^{30}$ Andrews, "The Southern Telegraph Company, 1861-1865: A Chapter in the History of Wartime Communication."
} 
The growth in the industry and the revenue injection led towards the development of new journalistic paradigms in conflict coverage. Competition to be the first on the scene was generated, as well as demand for exclusivity and rapid turnaround to the public. ${ }^{31}$ While the competitive news environment led to the establishment of these principles, they were rarely met in Northern correspondence. ${ }^{32}$ Riddled in sensationalism, dishonesty, partisanship and slander, objectivity fell and was replaced with often untruthful and unbalanced reports. The South, with significantly less of a developed press, mostly weeklies, did not have enough resources both financially and in the labour force. The journalistic work coming from the Southern States was partisan, crawling with propaganda, and owing to a lack of resources, journalists were censored (enforced by editors and the state) and used as a military tool. Journalists covering the war lost their independence, accepting and taking on second jobs within the armed forces. Knightly calls the period between 1861 to 1865 , "[O]ne of the poorer periods in the progress of the war correspondent...however [it did] have the effect of making war correspondence a separate section in the practice of journalism." ${ }^{33}$ The Civil War introduced extensive war coverage to mass media leading to a more nuanced conversation in the political public sphere. ${ }^{34}$ These conditions set the stage for the golden age of war correspondence, marking a time with little organized censorship, continuous expansion of the mass press, as in Britain, literacy exploded by virtue of the Education Act of 1870 .

\footnotetext{
${ }^{31}$ Knightley, The First Casualty : From the Crimea to Vietnam : The War Correspondent as Hero, Propagandist, and Myth Maker, 21.

32 Knightley, 21.

${ }^{33}$ Knightley, 41.

${ }^{34}$ Knightley, 43.
} 


\subsection{The Franco-Prussian War (1870-1871)}

For the Western public, the Franco-Prussian War was the most expensive war to cover $^{35}$ to date on the grounds of the high cost of using the telegraph to communicate internationally. However, it was the first use of wireless transmitting from the scenes of battle and regardless of the cost. Unlike the Crimean War, which was primarily covered by the British, at least six different countries sent correspondents to cover the war. The telegraph sped up transmission time, but the cost and nature of the medium marked a new era of war reporting resulting in a transformation of the ways stories were written. The writing style switched away from the elaborate and artistic descriptions that were often characterized in Russell's accounts into sharp, tightly written reports, which were cheaper to send across long distances. The Franco-Prussian War illustrates that the format in which the reporting is delivered shapes the message being received by a journalist's audience. The journalism writing style, employing short, simple sentences, attempting to most compactly answer the who, what, where, why, how, and "so what" remains a standard characteristic of present time journalistic writing.

\subsection{World War I (1914-1918)}

${ }^{35}$ Roth, Historical Dictionary of War Journalism, 110. 
World War I (WWI) was a 'total war' conducted not only by nation-states and their militaries but an organized effort from the population at large-including journalists and the press. When war broke out, the mass press jumped on the opportunity to cover the conflict out of economic interest. Not yet having entered the war, the US sent 50-75 correspondents in 1914 to Europe. The US Army refused to accredit women to action on the western front, even though they had been active before America joined the conflict. To get around this, there were some women journalists who covered the war from the Russian front. WWI ended up being the safest conflict for American journalists. Although some were wounded, there were no civilian journalists killed during the war. "British-based Reuters, by comparison, lost at least 15 of 115 [war correspondents]."36 Once the US engaged in 1917, the number of journalists covering the warfront grew dramatically to several hundred in the final year. "War not only creates a supply of news, but a demand for it," wrote an anonymous Northcliffe editor. ${ }^{37}$ Western journalists quickly became stationed in Europe, and before the Americans joined the war, journalists could move freely through Berlin and other capitals. ${ }^{38}$ During the initial years of the conflict, many foreign correspondents were indulged by the luxurious accommodations that provided motorized transportation, servants, haute cuisine, tobacco, and wine offered to them by the Austrian government.

\footnotetext{
${ }^{36}$ Roth, 351-52.

${ }^{37}$ Knightley, The First Casualty : From the Crimea to Vietnam : The War Correspondent as Hero, Propagandist, and Myth Maker, 89.

${ }^{38}$ Roth, Historical Dictionary of War Journalism, 351-52.
} 
An absolute case can be made that the origins of embedded reporting were established in WWI. Six journalists were embedded in the British Expeditionary Forces (BEF). "The correspondents were embedded with the BEF in France, given the honorary rank of captain, wore uniforms, and were assigned orderlies, chauffeurs and conducting officers: however, their first view of the war was limited to what the general staff felt they should see." ${ }^{39}$ Lord Kitchener appointed officers for eye-witness daily reports about the war, which would bear his stamp of approval — they were tightly controlled and subject to censorship by London's War Office. The War Aims Committee, eventually expanding to become the Ministry of Information, was an effective organization of propaganda and disinformation. It became the model that the Germans would use 20 years later. ${ }^{40}$ Knightly argues that if people knew what was truly happening on the western front, it would be unfathomable to believe that people would engage in the war. He blames the British war correspondents, who, although they played witness to the heinous battles, saw themselves as protectors of the BEF.

The First World War was Canada's first major appearance on the European battlefront and played a significant role in developing Canada's autonomy and international recognition. Sir Robert Borden's administration passed the War Measures Act which allowed censorship control and suppressions of publications, writings, maps, plans, photographs and communications when deemed necessary for the security,

\footnotetext{
${ }^{39}$ Wasilow, "Contemporary Canadian Military/Media Relations: Embedded Reporting during the Afghanistan War," 23.

${ }^{40}$ Knightley, The First Casualty : From the Crimea to Vietnam : The War Correspondent as Hero, Propagandist, and Myth Maker, 86-89.
} 
defence, peace, order and welfare of Canada. The Chief Press Censor was established in 1915 to safeguard the press from "assisting or encouraging the enemy, or preventing, embarrassing, or hindering the successful prosecution of the war." ${ }^{\text {41 }}$ Canadians supported their troops and patriotism ran so high that the need for censorship was dispensable. In 1917, Canada suffered a military crisis over the ongoing disagreement about conscription. French Canadians considered their loyalty to Canada over any colonial ties to Brittan or France, igniting anti-war sentiment. Most publications that were censored in Canada originated in America. Canadian coverage of the warfront was forbidden by the British until 1915, when the government appointed William Maxwell Aitken, later the Right Honourable Lord Beaverbrook, to the frontlines. Beaverbrook had made his wealth in Canada, made his way to Great Britain to become a member of Parliament and began purchasing newspapers. When the war broke out, Beaverbrook served as the Canadian reporting home to the Canadian government from the frontlines and wrote columns for the Canadian and international press. By the same token, Beaverbrook functioned as a publicist for the CF, constructing the Canadian War Records Office and praising the Canadian Expeditionary Force (CEF). In the last year of the Great War, Beaverbrook was appointed as Minister of Information, which managed British war effort propaganda. Propaganda became an instrument of control over the public opinion, a weapon of war, and Beaverbrook "nurtured a relentless campaign extolling the heroic deeds of Canadians. ${ }^{42}$

\footnotetext{
${ }^{41}$ Keshen, Propaganda and Censorship During Canada's Great War, 66.

${ }^{42}$ Cook, "Documenting War and Forging Reputations: Sir Max Aitken and the Canadian War Records Office in the First World War," 265.
} 
Beaverbrook was the most influential Canadian-British journalist to cover WWI, playing both the roles of a propagandist and journalist. The journalists that he published were treated as in-house writers, with much of the copy done by Beaverbrook himself.

Journalistic features accentuating Canadian exploits, the commissioning of artists, photographers and cinematographers to craft works with a Canadian content, the creation of commemorative journals, and even the publication of the first popular war histories, all helped to shape a distinctive Canadian identity...largely at [Beaverbrook's] discretion... ${ }^{43}$

The Canadian journalism of WWI assisted in creating the image of a Canadian identity. On the Canadian side, Sir Robert Borden's government and the British side, the David Lloyd George government, had very effectively used the media for a political purpose for the first time. Propaganda was used to control public opinion and as a weapon of war. The professional journalistic norms of objectivity and independence had well been established in the US and Britain, but at the time of WWI, it had not seeped its way into Canadian journalistic tradition yet. ${ }^{44}$ The discreditable coverage of WWI by Canadian journalists generated the groundwork for the self-censorship they would continue employing in WWII.

${ }^{43}$ Cook, 2.

${ }^{44}$ Basen, "Why Canadian Media Embraced Censorship during WWI." 


\subsection{World War II (1939-1945)}

World War II (WWII) is often considered the most censored war in an era where the western war correspondents were romanticized to become war heroes, including Canada’s Ross Munro, Gregory Clark, Matthew Halton, and Peter Stursberg, and America's Walter Cronkite, Alan Moorehead, Edward. R. Murrow, Ernie Pyle, and William L. Shirer. Worldwide radio broadcasters had been introduced in the 1930s. While television existed, it was scarcely known, and journalistic audiences would receive information through the use of newspapers, radio and motion pictures. Most famous in this time is Edward Murrow broadcasting for Columbia Broadcasting System, (CBS), whose voice narrated the war to Americans, and columnist Ernie Pyle for ScrippsHoward newspapers, who was killed in action during the Okinawa campaign in the Pacific. Over 3000 correspondents covered the war. More than half were from the USA, with 1646 accredited around the world, including 100 women. ${ }^{45}$ Thirty-seven American correspondents and photojournalists would perish. As a war that took place on several fronts, WWII was challenging to cover because not only were journalists geographically scattered, but there were also simultaneous campaigns and battles in process.

Just as in WWI, American war correspondents wore military uniforms and received honorary titles of officers resulting in conflict coverage that was inflected by patriotism, stoicism, and jingoism. Censorship materialized in three main ways - military censorship, governmental censorship, and self-censorship. Correspondents signed agreements that

\footnotetext{
${ }^{45}$ Roth, Historical Dictionary of War Journalism, 352.
} 
required that they submit all their material through military channels before they went through the federal government Office of Censorship. There was self-censorship where a journalist purposely omitted information from their reporting. This was both done with information that they knew was sensitive but also in times when a censor thought it should be withheld from civilians for the sake of their morale. "I wouldn't tell the people anything until the war is over, and then I'd tell them who won," is an often-quoted line and has also been quoted as, "tell them nothing till it's over and then tell them who won." 46

According to an American broadcast journalist for the CBS Evening News, Walter Cronkite's account of WWII, "[J]ournalists embedded with the allied units would tell the Allied Forces where they wanted to go, and the unit would make arrangements. By his account, correspondents were rarely restricted from military operations and had access to jeeps with government-issued drivers to bring them to the front lines." ${ }^{\prime 47}$

He believed in the importance of censorship but recounted being able to appeal should the contents of an article be censored. A familiar anecdote is often cited, where Charles Collingwood, one of "Murrow's boys," accidentally asks another journalist who he mistook as a naval officer on live television to describe the D-Day scene at Omaha Beach, Normandy. He replied, "Beats the shit out of me, Charlie. I'm the NBC

\footnotetext{
${ }^{46}$ Wasilow, "Contemporary Canadian Military/Media Relations: Embedded Reporting during the Afghanistan War," 26; Knightley, The First Casualty : From the Crimea to Vietnam : The War Correspondent as Hero, Propagandist, and Myth Maker, 293.

${ }^{47}$ Price, "Inside the Wire: A Study of Canadian Embedded Journalism in Afghanistan," 19.
} 
correspondent." The mishap arose because journalists were in military uniforms—while Collingwood was in an army uniform, the NBC correspondent was in a navy uniform.

It is estimated that there were over 50 Canadian foreign correspondents, ${ }^{48}$ marking a substantial difference between the several 'Eye Witnesses' under British supervision that saw the frontlines of WWI. In Canada, there was a War Time Information Board, and a civilian-led Directorate of Censorship within the Department of War Services, which "was responsible for the security of information in newspapers, radio and film, as well as in postal and telegraphic communications. ${ }^{49}$ Canadian journalism could often be described as " "democratic propaganda" grounded in truth," which for the purpose of high morale was seemingly optimistic about war. ${ }^{50}$ The mass press was preoccupied with wartime efforts. The newspapers were filled with war efforts on both domestic and international levels, even depicted in cartoon sections. ${ }^{51} \mathrm{~A}$ conducting officer regularly escorted Canadian journalists. However, they were allowed to interview soldiers and civilians and record or write down what they wanted. All the information that would be transmitted back to Canada first underwent a series of checks and censors according to military rules and timetables. The journalistic material would undergo another formal censorship under the War Measures Act by the Canadian government. Finally, before being publicized, the reports and broadcasts were subject to the scrutiny of editorial decisions in the pressroom and the newsroom.

\footnotetext{
48 Thompson, "Canadian Warcos in World War II: Professionalism, Patriotism and Propaganda," 57.

49 "Democracy at War - Information, Propaganda, Censorship and the Newspapers."

50 "Democracy at War - Information, Propaganda, Censorship and the Newspapers."

51 "Democracy at War - Information, Propaganda, Censorship and the Newspapers."
} 


\subsection{The Vietnam War (1955-1975)}

The Vietnam War was the first televised war bringing the war inside the homes of Americans. The military's relatively ad hoc approach of journalistic access to the battlefront became schematized procedures marking a turning point in journalistic conflict coverage. ${ }^{52}$ The American government, along with military officials, did not employ mandatory censorship of the press. Since the coverage of WWII was fueled with propaganda and journalists saw themselves as part of the war effort, the US military provided flexible means for reporters, giving them unprecedented access to both information and the frontlines because they did not expect the public outlash that ensued. The Pentagon was blindsided in their assumption that coverage of the Vietnam war would have the same eager support as in WWII.

The 10-month-long, Tet Offensive, was one of the significant turning points in the Vietnam War, providing a massive political victory for the Allied forces. Kennedy views it as the most iconic moment of journalistic failure as prior coverage rarely showed combat. It opened the endless debate as to whether the media should attempt for a most accurate representation of an ongoing war or should it be an arm of the state. Taking responsibility for keeping patriotic morale high, for war, in the case of Vietnam, was likely a failure from its onset. The now termed "Cronkite Moment," named after famous

\footnotetext{
${ }^{52}$ McLaughlin, "Goodbye Vietnam Syndrome: The Embed System in Afghanistan and Iraq."
} 
news anchor Walter Cronkite represents a time of shifting media perspectives of the war. While Cronkite, like most journalists at the time, initially supported the fight against Communism and avoided describing scenes of death and devastation during the Tet Offensive, his tone changed, reporting on the gruesome death tolls and calling the war a stalemate. Losing public support for the war tipped a domino in a series of events that pushed President Lyndon B. Johnson not to seek re-election and famously state, "If I've lost Cronkite, I've lost [middle] America."

Allied forces unquestionably lost the Vietnam war. However, former presidents Johnson and Richard Nixon used the revisionist term, the "lost victory." It purported that it was the 'Vietnam Syndrome,' not military failure, that led to the loss of the war, that it was the news media which undermined public support for the war, leaving Americans with little hope and will to continue in the war effort. The Nixon era discourse centred around reprehending mass media for demoralizing the American population, questioning if they could ever be unified as a nation in wars to come. This rhetoric shattered militarymedia relations for many years to come.

Naturally, the perspective that the media lost the war was equally held by the military. The accounts and images published were brutal, with pictures of starving children, villages ablaze, mass murder, and stories of military atrocities. The gruesome reports from the frontline countered the Pentagon's narrative, leading to anti-war sentiment. 
Kennedy writes, "In fact, there was no evidence then, and is none now, to support this theory of a television-induced collapse of will on the part of the American public..." and cites John McWethy of ABC, in the US Naval Institute Proceedings:

There is a tendency in the military to blame our problems with public support on the media...The majority of the on-the-scene reporting from Vietnam was factual — that is, reporters honestly reported what they had seen firsthand. Much of what they saw was horrible, for that is the true nature of war. It was this horror, not the reporting, that so influenced the American public. ${ }^{53}$

The Vietnam War was perhaps one of the least censored wars, or at least the closest to journalistic ideals of independence that had ever been reached before. However, it marks a critical point in the denigration of civil-military relations, one often in the back of policy-maker's minds when making decisions in the future about how the media should be handled.

\subsection{The Falklands War (1982)}

Still reaping the losses, officials in the American government were touting the line that American television had lost the Vietnam war. The British Ministry of Defence (MOD) planned their press strategy as not to fall for the same ploy as did the Americans.

\footnotetext{
${ }^{53}$ Kennedy, The Military and the Media: Why the Press Cannot Be Trusted to Cover a War, 31:112.
} 
The already unpopular government of Margret Thatcher, largely because of the high unemployment rates, only allowed for a small and exclusive group of reporters to join their Task Force. The coverage was so highly censored that reports took an average of 17 days before airing in Britain. "[M]edia management for the Falklands War was premised on the idea that war in the television age could be "won" by imposing severe restrictions on television, which would, in turn, minimize the public's exposure to negative representations of the British forces. ${ }^{\prime 54}$ Every story had to be reviewed by onsite government officials and often the MOD bureau in London, who delayed the transmissions that threatened public morale. In practical terms, it was thus much faster to transmit news of the 74-day campaign through the radio.

\subsection{The Gulf War (1991)}

The problem [in the conflict journalism during the Gulf War] is how journalists responded to propaganda from what they might see as their' own side' as well as a host of other failures: their unwillingness to challenge reporting restrictions; their readiness to betray their own colleagues for minor advantage; their enjoyment of the razzmatazz of the military briefings; their susceptibility to disinformation and dissemble; and their failure to corroborate source information against alternative material. And while they complained or expressed regrets about all this after the war, the US military personnel were already thinking ahead

\footnotetext{
${ }^{54}$ Wasilow, "View of Hidden Ties That Bind: The Psychological Bonds of Embedding Have Changed the Very Nature of War Reporting."
} 
and planning the next stage of development: the embed system that they first tried out in Bosnia after the Dayton Accords in 1995 and fine-tuned by the time it was rolled out for the invasion of Iraq in 2003 ... it was a propaganda triumph. ${ }^{55}$

Military-media relations were troubled in reaction to the restricted access that journalists faced in covering the Persian Gulf War (1990-1991). The restraints to access that the journalists faced were primarily a response to the strong sentiment that the American media lost the Vietnam War before its military did. ${ }^{56}$ Impressed by the political information policy that the British military employed throughout the Falklands War, the Americans developed their own pooling system. The Pentagon attempted to parallel the successful tactics to control wartime news coverage that the British MOD had implemented during the Falklands War, started using the British system of press pools, called media reporting teams. ${ }^{57}$

Press pools consist of around 11 journalists from several different news outlets, combining their resources and equally distributing their journalistic material across its members. The pools were designed to give access to mass media covering the American troops while escorting the reporters in remote areas. Each press pool was accompanied by public affairs agents who had control over what the journalists experienced.

In the time of the Persian Gulf War, a press pool was made up of one wire-service photographer and correspondent, one magazine correspondent and a photographer, and

\footnotetext{
${ }^{55}$ McLaughlin, “Goodbye Vietnam Syndrome: The Embed System in Afghanistan and Iraq," 140.

${ }^{56}$ Mordan, "Press Pools , Prior Restraint and the Persian Gulf War," 6.

${ }^{57}$ Wasilow, "Contemporary Canadian Military/Media Relations: Embedded Reporting during the Afghanistan War," 41; McLaughlin, "Goodbye Vietnam Syndrome: The Embed System in Afghanistan and Iraq," 118.
} 
three newspaper reporters. ${ }^{58}$ It was more restrictive than any pooling system used before. "[A] more formal and restrictive pooling system than that used in both World Wars...coupled with tightly managed daily media briefings, suggests that the historical development of military media strategy has been evolutionary rather than revolutionary or new." 59

Reporters would have access to and subject their stories to review. The use of pools allowed the news to be controlled yet still have journalists report "independently," although through a highly restrictive lens. "[O]perations were carried out with most journalists under the thumb and the public in the dark. In this regard, the pooling system was successfully 'activated' in every instance while journalists, on the other hand, were effectively deactivated." ${ }^{60}$ It was an improvement after the media blackout that the American military employed during Operation Urgent Fury, the Grenada invasion in 1983. In the first days of the Grenada occupation, the American military authorities did not allow journalists into the Caribbean island. While journalists screamed censorship, the necessity and demand for information in the political public sphere were so high that it created competition between journalists and their respective news outlets. This was the origin of the term "unilaterals" to describe the correspondents who worked independent of the military and not in press pools. During the Gulf War, as many as 20 unilateral reporters, who were pitted against the journalists in the press pool, were detained or sent back to Dhahran in Saudi Arabia.

\footnotetext{
${ }^{58}$ Fialka, Hotel Warriors: Covering the Gulf War, 2.

${ }^{59}$ McLaughlin, "Goodbye Vietnam Syndrome: The Embed System in Afghanistan and Iraq," 118.

${ }^{60}$ McLaughlin, 140.
} 
The Pentagon would unleash a historically ground-breaking effort to control the dominant news narrative in branding exercises through the use of public relation (PR) firms. Government officials compared the Iraqi invasion and occupation of Kuwait to the Nazi blitzkrieg. Saddam Hussein was likened to Adolf Hitler, and many false stories surrounding Iraqi soldiers emerged. The harrowing reports coming from the US government bolstered the hearts of the American public and drove the campaign that would support US military intervention. Much of the sensationalist discourse that was being pushed by American officials can be attributed to the American PR firm Hill \& Knowlton. The PR group was hired by the US administration to administer public opinion polls on the American appetite for war. "The end result was that the public's perception and understanding of the war, the reasons for fighting, and the very meaning of the consequences of hostilities were so fundamentally guided by the media's (and the Pentagon's) representations that for many, the war became more symbolic than realistic. ${ }^{\prime 61}$

The term "CNN effect,"—CNN being the Cable News Network—-sometimes called the "CNN factor," originated from the coverage at this time. It contends that television images can shape foreign policy. Television news hailed such an influence over the political-public sphere that $\mathrm{CNN}$ was referred to as the $16^{\text {th }}$ member of the United Nations Security Council (UNSC) by the former United Nations (UN) Secretary-General Boutros Boutros-Ghali. The 24-hour CNN and other news media outlets that had

\footnotetext{
${ }^{61}$ Wasilow, "View of Hidden Ties That Bind: The Psychological Bonds of Embedding Have Changed the Very Nature of War Reporting."
} 
international coverage were studied by academics, media commentators and the military under the context that:

varied between the extremes of support for a globe-shrinking information tool capable of sharing western consciousness to the less fortunate in distant lands, versus disparagement of a medium that was said to undercut rational contemplation, encourage public emotionality, and force instant responses in situations that required careful decision making. ${ }^{62}$

The "CNN effect" is focused on international attention on hotspots. While some conflicts were brought to the forefront of a North American public, others were not. The coverage of the Tiananmen Square protests, the fall of communism in Eastern Europe, and the Gulf War were exceedingly scrutinized, while the Rwanda genocide rarely made the spotlight. The Canadian contribution to the United Nations Assistance Mission for Rwanda (UNAMIR) from 1993 to 1995 received little media attention. The campaigns that led to the killing of $80 \%$ of the country's Tutsi population were not reported in the media, until three weeks into the event, when already a quarter-million people had died. The Western press has accused of subverting its ethical responsibilities by failing to signal to the international community the ongoing carnage.

\subsection{Somalia (1992)}

It was difficult for the Department of Defense (DoD) to control news media coverage of the Somalia intervention because the operation was announced well before it

\footnotetext{
${ }^{62}$ Wasilow, "Contemporary Canadian Military/Media Relations: Embedded Reporting during the Afghanistan War," 49-50.
} 
began, and the media "took the opportunity to "unilaterally [take] up post in the theater of operations before the military arrived." ${ }^{63}$ As a result, the press had unrestricted access. The Clinton administration withdrawal from Somalia in 1994, retrospectively viewed as pre-emptive, is believed to have been the result of pressure exerted by the political-public sphere. The American public was outraged by the photos and videos of American soldiers being dragged through the streets of Mogadishu, that circulated through the press.

Writing for The Philadelphia Inquirer, journalist Mark Bowden penned a 29-part series, that was later compiled in the book Black Hawk Down: A Story of Modern War. In this series, Bowden contextualizes how the peacekeeping efforts by the American-led multinational task force devastatingly devolved into close combat, erroneous raids, civilian deaths, and the downing of two Black Hawk helicopters. Bowden's book was adapted into a film in 2001. Becoming a classic of conflict reporting, Black Hawk Down tells the story of the 99 American soldiers who were trapped in Mogadishu. The reporting draws from classified combat video and radio transcripts and interviews that compile a profound and deep-seated coverage. The Black Hawk Down incident is often referred to as the Battle of Mogadishu and profoundly impacted the American public. Canadian photographer Paul Watson captured photos of the Somali warlord Mohammed Aideed's supporters cheering while dragging the body of the Black Hawk pilot, Staff Sgt. William David Cleveland, through the streets of Mogadishu. The Pulitzer Prize-winning shots, published in Time magazine and the New York Times, altered the American war course. Shortly after the incident, former President Bill Clinton withdrew American soldiers with

\footnotetext{
${ }^{63}$ Paul and Kim, "Reporters on the Battlefield: The Embedded Press System in Historical Context," 46.
} 
other Western nations shortly following suit. With Bowden's reporting and Watson's photographs left in the minds of Americans, the admonished US government became reluctant to be involved in future African crises, expressly in the Rwandan genocide a year later. The Battle of Mogadishu harrowed such politically potent photos that in 1996 Osama bin Laden used it as proof of the American unwillingness to so stomach casualties when "one American was dragged in the streets of Mogadishu you left; the extent of your impotence and weaknesses became very clear."64

As for a Canadian example of the CNN effect, the collapse of the Somali government in 1991 and the Canadian Armed Forces (CAF) participation in the UN Peacekeeping mission from 1992-1993 received a lot of media recognition. In Canada, a different set of photos shocked the public. Pictures emerged of a Somali teenager who had been tortured to death at the hands of two soldiers in the Canadian Airborne Regiment. Shidane Arone was found hiding in an abandoned American base. Fearing that Arone would attempt to steal supplies from the Canadian base close by, he was detained by soldiers in the Airborne Regiment. Within less than a day, he was found beaten and tortured to death. A Canadian reporter, Jim Day, for the Pembroke Observer, was on the base at the time and broke the story of the Canadian soldiers who were being heled pending the death of a Somali citizen. It was only after Day witnessed the unconscious body of Master-Cpl. Clayton Matchee, who had attempted suicide after he had been arrested in Arone's death, being carried by stretcher to the medical facility that Day unveiled the scandal. Day's reporting resulted in explosive revelations about Arone's

\footnotetext{
${ }^{64}$ Bethune, "THE GHOST OF A MAN I NEVER KNEW."
} 
death. It eventually motivated a 25 million dollar commission of inquiry. "Day's discovery developed into a scandal that would profoundly shock Canadians, tarnish the country's international image, dominate national politics for five years, and harm the reputations of numerous high-ranking officers and defence officials." ${ }^{65}$ Arone's death and its subsequent coverup garnered such public disgrace that the regiment was disbanded, and Canadian military spending was cut by nearly 25 percent. ${ }^{66}$ The Somalia Affair haunts the Canadian reputation, a fallout that marks a disturbing chapter in Canadian military history.

While this took place before the official Canadian Forces Media Embed Program (CFMEP), Day was on an escorted trip in Belet Huan, a junket funded by the Department of National Defence (DND) to generate coverage of the mission. The torture killing of Arone might never have come to light without the DND-funded junket. ${ }^{67}$ The Canadian reputation as a leading peacekeeping nation that had peaked in the 1980s diminished in the 90s. The DND media junket in which Day had participated is an example of how the Canadian military is, and continues to be, reflective and deliberative in its publicity. The military's effort to generate coverage of their mission would become more convoluted for reporters in the future, creating hurdle after hurdle. The desire of Canadian journalists to be under the protection of the $\mathrm{CF}$ also grew during this time. Fresh in their memories was freelancer Amanda Lindhout's story, who had been taken hostage and held for ransom for 15 months.

\footnotetext{
${ }^{65}$ Foot, "Somalia Affair."

${ }^{66}$ Hurley, Turning around a Supertanker: Media-Military Relations in Canada in the CNN Age.

${ }^{67}$ Murray, "The Faces of Somalia."
} 


\subsection{Bosnia (1995) and Kosovo (1999)}

The first developments of limited embedding programs constituted by the US Air Force were used during the humanitarian operations in Bosnia and Kosovo. The military had advanced management and control of the media that began with direct control of affairs through overt and unhindered censorship, then moulding into restricted access, and eventually put in motion the press pooling system and finally mobilizing the beginnings of an embedding system. Instead of outright hostility towards the media, what was found to be a more effective form of control, was to rely on the adherence and loyalty of journalists to the terms in which they release information and to their patriotism. 68 "In Bosnia in 1995 the term "embedded press" was first used to describe a style of press procedures similar to those used in the days of World War II and Vietnam, although far more formal and planned." 69 There was a total of 33 reporters attached to military units representing 24 media organizations, both American and foreign news media outlets. ${ }^{70}$

The North American Treaty Association (NATO) led international peacekeeping force in Kosovo provided air support to the Kosovo Liberation Army through a series of bombing campaigns in Yugoslavia. While there were embedded reporters in Operation Allied Force because the operation was limited to air support in 1999, the reporters had less access to the front lines. A reporter from the air could observe the bombings, but the

\footnotetext{
${ }^{68}$ McLaughlin, The War Correspondent.

${ }^{69}$ Paul and Kim, "Reporters on the Battlefield: The Embedded Press System in Historical Context," 48.

70 Paul and Kim, 48.
} 
effects of the bombings are less visible at such a height ${ }^{71}$ - furthermore, the Pentagon severely limited press access in the name of operational security.

"The experience of Kosovo in 1999 illustrated the difficulty of preventing the press from gaining access to information in an age of technology," wrote Christopher Paul and James J. Kim. ${ }^{72}$ Since reporters had such limited access to information, they turned to the adversary, Slobodan Milošević's, the Yugoslav and Serbian politician's command for details on the development. The Pentagon's effort to obstruct journalists from the frontlines backfired as the journalists were given access to "sites of collateral damage resulting from the allied bombing campaign," which were so graphic that it led to reports questioning the moral authority of the NATO campaign. ${ }^{73}$ As the Pentagon became aware that it was problematic to constrain reporters' access, they "determine[d] how to proactively implement a system of press relations that maximizes operational security while providing sufficient press access to prevent damaging enemy misinformation from playing undisputed in the news. ${ }^{74}$ So bore the need for modern-day embedding programs.

\subsection{The US War in Afghanistan (2001-2020)}

\footnotetext{
${ }^{71}$ Paul and Kim, 49.

${ }^{72}$ Paul and Kim, 49.

${ }^{73}$ Paul and Kim, 49.

${ }^{74}$ Paul and Kim, 49.
} 
The US administration framed ${ }^{75}$ their intervention in Afghanistan under the justification of fighting the Taliban and Osama bin Laden, the founder of Al-Qaeda, as well as on the ideological allying of "saving" the women of the Middle East. ${ }^{76}$ Western media coverage of Afghanistan following 9/11 predominantly took its cues from the US administration, seizing the burqa as a symbol of the infringement of Afghan women's rights and dignity that needed protection from the Taliban. The news media contributed to this narrative comparing “outrage and sorrow over the attacks with a nation's resolution to wreak vengeance..."77 Only weeks after al-Qaeda operatives hijacked four commercial airliners, crashing them into the Pentagon and the World Trade Center, Canada, Australia, Germany, and France pledged their support for launching Operation Enduring Freedom.

In the early days of the war, American journalists could not get into Afghanistan. They were stopped at the border and were denied entry into the country. Much of the journalism that was produced about Afghanistan prior to the embed program, was produced in the neighbouring country, Pakistan. While there was no embedding program yet, journalists could sign on with the US military, allowing them to be on the Bagram Airbase, where they endured very limited access to areas where the attacks were launched. The restrictions they faced were more significant than that the limits placed on

\footnotetext{
${ }^{75}$ More on framing in chapter 2

${ }^{76}$ Rich, "Saving' Muslim Women: Feminism, U.S Policy and and the War on Terror"; Wasilow, "Contemporary Canadian Military/Media Relations: Embedded Reporting during the Afghanistan War," 53; Fahmy, "Picturing Afghan Women: A Content Analysis of AP Wire Photographs During the Taliban Regime and after the Fall of the Taliban Regime."

${ }^{77}$ Wasilow, "Contemporary Canadian Military/Media Relations: Embedded Reporting during the Afghanistan War," 53.
} 
the coverage of previous operations. Furthermore, they were not allowed to interview Special Operations personnel which made the conflict difficult to cover since most landbased operations were done by special operation forces — whose equipment and techniques were classified. ${ }^{78}$ Strong complaints from journalists eventually led to the end of the press pooling system, and high authorities began the discussions on a formal embedding program. Such a conversation would seem inevitable as technological advances such as portable satellite-transmitting devices increased the publishing rates.

\subsection{The Iraq War (2003-2011)}

The Iraq War is another significant era for conflict coverage as it was the first war broadcast on live television as well as Operation Iraqi Freedom (OFI), proceeded with the first large-scale embedding program, which gave the press the greatest access they had had in any war since Vietnam. Post 9/11, the news media held an enormous influence over the American public, with television news realizing a new high level of respectability. The magnitude of the major combat operation came with great public international interest and accordingly required a comprehensive media management plan from the Pentagon.

There does not seem to be a clear consensus in the literature about when or how the embedding program in the Iraq War was conceived. Knightly contends that the embedded

\footnotetext{
${ }^{78}$ Paul and Kim, "Reporters on the Battlefield: The Embedded Press System in Historical Context," 51.
} 
reporting system was not created in the planning stage of the Iraq invasion, while other commentators, such as Greg McLaughlin hold that it was developed between the end of the Bosnian War where the US military played a large role in the United Nations Protection Force in the Balkans. Spearheaded by William L. Nash, the commanding general of the American sector during the initial deployment of NATO troops to Bosnia, the system had three objectives in respect to dealing with the media: to gain public support; use media to build up compliance with the Dayton Accords; ${ }^{79}$ use the media to promote compliance by the former warring factions to the Dayton Accords; to reinforce soldiers' morale. ${ }^{80}$ He wrote, "I was determined not to be in the same position in which General William Westmoreland found himself in Vietnam, forced to attempt to justify the intervention itself, to explain the politics and the military performance at the same time." 81

The first official embedding program gave journalists access to service members and operational combat missions. Under the American policy, embedded journalists could not become 'unembedded.' That is to say, the reporters would remain under the confines of their hosts and could not leave their protection to write stories independently, often referred to as "outside the wire." Should a journalist have wished to do so, they would have had to leave the embedding program permanently.

\footnotetext{
${ }^{79}$ The General Framework Agreement for Peace in Bosnia and Herzegovina are often referred to as the Dayton accords or Dayton agreement.

${ }^{80}$ Nash, "The Military and the Media in Bosnia," 131-32.

${ }^{81}$ Nash, 131.
} 
The embedded reporters would sign a formal policy agreement with their hosting institution. It outlined that all interviews would be 'on the record' and included a list of releasable and non-releasable information. In exchange for being hosted by the military, journalists agreed not to release the following information unless specifically released by the DoD or otherwise authorized: information regarding future operations; force protection measures at military installations; photography of the level of security at military installations; the rules of engagement; information on intelligence collection activities compromising of tactics, techniques or procedures; extra precautions will be required at the commencement of hostilities to maximize operation surprise; live broadcasts until the safe return; during an operation-specific information on friendly force troop movements, tactical deployments, and dispositions that would jeopardize operation security or lives; information on ongoing engagement will not be released; information on special operations units, unique operations methodology or tactics; information on the effectiveness of enemy electronic warfare; information identifying postponed or canceled operations; information on missing or downed aircraft or missing vessels while search and rescue and recovery operations are being planned or underway; the effectiveness of enemy camouflage, cover, deception, targeting, direct and indirect fire, intelligence collection, or security measures; photographs of enemy prisoners; and stills or video imagery of custody operations. ${ }^{82}$

As the landscape became more violent it was safer for news outlets to make use of the embed program. At the beginning of 2003, there were about 700 embedded journalists

\footnotetext{
82 Defence, "Public Affairs Guidance (PAG) on Embedding Media."
} 
with the American troops from almost 250 news organizations. ${ }^{83}$ In total, there were approximately 1,000 foreign and domestic media representatives, ${ }^{84}$ many of which were unilateral reporters who entered Afghanistan independently to work with local fixers or and the Northern Alliance troops. By springtime, when American troops had moved into Iraq, there were only 26 remaining embeds and very few by 2004 as most journalists remained in Baghdad. ${ }^{85}$ By 2008, there were around nine embedded reporters left. ${ }^{86}$

Since the inception of the war, public opinion had taken a dramatic shift. On the onset of the war and initial attacks in Baghdad, a majority of Americans believed the Bush administration's messaging, about the presence of weapons of mass destruction (WMD) in Iraq and that Saddam Hussein was directly linked to the $9 / 11$ attacks. ${ }^{87}$ Much of the reporting on information about Iraq's WMDs by the New York Times journalist Judith Miller was later found to be widely inaccurate, even erroneous. As the sole embedded journalist with the $75^{\text {th }}$ Exploration Task Force, she "helped convey the impression to the nation that illicit weapons had been found in Iraq, supposedly validating the decision for war," ${ }^{88}$ Wasilow writes, "Miller saw her role as that of a relayed or messenger [of government fed intelligence] - an approach which places her firmly within the cheerleading narrative of military/media relations that existed during the Vietnam War

\footnotetext{
${ }^{83}$ Sylvester, Reporting from the Front: The Media and the Military, 7, 54; Price, "Inside the Wire: A Study of Canadian Embedded Journalism in Afghanistan," 29.

${ }^{84}$ Wasilow, "Contemporary Canadian Military/Media Relations: Embedded Reporting during the Afghanistan War," 57.

${ }^{85}$ Sylvester, Reporting from the Front: The Media and the Military, 59-60.

${ }^{86}$ Local, "Journalists in Iraq : A Survey of Reporters on the Front Lines."

${ }^{87}$ Child and Casper, "Embedded Reporting and Audience Responce in the Iraq War"; Policy et al., "Reporters on the Battlefield: The Embedded Press System in Historical Context," 81.

${ }^{88}$ Abrams, "Weapons of Miller's Descriptions," 57.
} 
prior to $1968 . "{ }^{\prime 89}$ By 2008 , more than half of Americans believed that they were deliberately misled by the White House about the WMDs, that the war was not worth the cost and that Saddam Hussein was not linked to the $9 / 11$ attacks. ${ }^{90}$

Criticisms ${ }^{91}$ of the conflict coverage find models of framing and indexing to be an issue during the Iraq war. ${ }^{92}$ However, these were not limited to the practice of embedded reporting. They were also prevalent in the journalism practised by unilateral reporters. The comment upon the journalism produced through the practice of embedded reporting was that it provided a narrow scope of the conflict and was largely one-sided. ${ }^{93}$

Concerns of jingoistic biases are largely disproven by the existing research of the effects that embedding has on war coverage. Pfau, Haigh, Gettle, Donnelly, Scott, Warr, and Wittenberg (2004) found that embedded journalists produced more favourable coverage of individual troops and the military within the first five days of the Iraq War. ${ }^{94}$ Since this study covered a short period, it may have little external validity; the results could not be replicated, as reported by Aday, Livingston and Herbert (2005). ${ }^{95}$ This study found that embedded reporters had the highest percentage of neutral stories (91

\footnotetext{
${ }^{89}$ Wasilow, "Contemporary Canadian Military/Media Relations: Embedded Reporting during the Afghanistan War," 64.

${ }^{90}$ Child and Casper, "Embedded Reporting and Audience Responce in the Iraq War."

${ }^{91}$ An in-dept critique is offered in Chapter 2.

${ }^{92}$ Entman, "Cascading Activation: Contesting the White House's Frame After 9/11"; Bennett, Lawrence, and Livingston, "When the Press Fails: Political Power and the News Media from Iraq to Katrina."; Schechter, Embedded--Weapons of Mass Deception : How the Media Failed to Cover the War in Iraq . ${ }^{93}$ Child and Casper, "Embedded Reporting and Audience Responce in the Iraq War"; Schechter, Embedded--Weapons of Mass Deception: How the Media Failed to Cover the War in Iraq .

${ }^{94}$ Haigh et al., "A Comparison of Embedded and Nonembedded Print Coverage of the U.S. Invasion and Occupation of Iraq."

${ }^{95}$ Aday, Livingston, and Hebert, "Embedding the Truth: A Cross-Cultural Analysis of Objectivity and Television Coverage of the Iraq War."
} 
percent) and that they were more likely to produce positive stories featuring soldiers, battles, strategies, or tactics. Nonembedded journalists — in turn—displayed more of a focus on rival soldiers, civilian casualties and post-war reconstruction. ${ }^{96}$ The differences in reporting were not in positive or negative biases but in the framing ${ }^{97}$ of the stories. ${ }^{98}$ Similar research —done by Haigh, Pfau, Danesi, Tallmon and Bunko (2006) regarding the Iraq War-revealed that there were no significant differences between embedded and unembedded reporting in the tone of stories. Notable is that the majority of the considered coverage concerned episodic (frontline, hard news stories) reporting. ${ }^{99}$

In 2005, Shahira Famy surveyed 54 embedded journalists in a study called "How we Performed": Embedded Journalists' Attitudes and Perceptions Towards Covering the Iraq War. In attempting to measure the ambivalence of embedded journalists towards the first official embedding experiment in North America. Largely, the journalists had a positive view of their ability to report but agreed that their reporting only provided a narrow view of the conflict. ${ }^{100}$ "[Respondents] noted that their stories differed from the stories of non-embedded journalists and perceived both types of reporting as invaluable." 101

\footnotetext{
${ }^{96}$ Aday, Livingston, and Hebert.

${ }^{97}$ An in-dept look at framing is offered in Chapter 2.5.

${ }^{98}$ Aday, Livingston, and Hebert, "Embedding the Truth: A Cross-Cultural Analysis of Objectivity and Television Coverage of the Iraq War."

${ }^{99}$ Haigh et al., "A Comparison of Embedded and Nonembedded Print Coverage of the U.S. Invasion and Occupation of Iraq."

${ }^{100}$ Fahmy and Johnson, "Embedded and Perceptions Towards Covering the Iraq War."

${ }^{101}$ Fahmy and Johnson, “'How We Performed': Embedded Journalists' Attitudes and Perceptions Towards Covering the Iraq War."
} 
Using embedded journalists to potentially gain more positive conflict coverage was only one piece of the puzzle. A 2008 examination by The New York Times found that the Pentagon had been using retired military personnel and analysis to generate favourable news coverage of the administration's wartime performance, as “puppets of the Defense Department." 102 "[F]rom a military perspective, the American embed system was wildly successful. Journalists were kept under supervision and in close ties with soldiers, and their coverage centred on troop movements and combat from an American viewpoint." 103 Executive levels of government set the agenda for what the media reported. The outcomes of the embedded press system were a successful PR strategy because the journalism that was generated by embedded reporters, built credibility with the public, the press, and internationally, at a vital point. ${ }^{104}$ The DoD successfully deceived the American public through a campaign of disinformation that knowingly mislead the public to buy into the idea of a WMD presence in Iraq and that Hussein was responsible for the 9/11 attacks. Ultimately, it was the American public who suffered the consequences of yet another lost war.

\subsection{Canada and the Afghanistan War (2001-2014)}

The Canadian involvement in the Afghanistan War was Canada's longest war. As part of the Northern Alliance, which was formed after 9/11, the CF's objective to expunge the Taliban regime, which harboured in al-Qaeda camps. While at the end of 2001, the Taliban had lost control over most of their land. The UN and NATO allies,

\footnotetext{
102 Barstow, "Behind TV Analysts, Pentagon's Hidden Hand."

${ }^{103}$ Price, "Inside the Wire: A Study of Canadian Embedded Journalism in Afghanistan,” 32.

${ }^{104}$ Paul and Kim, "Reporters on the Battlefield: The Embedded Press System in Historical Context," 129.
} 
including Canada, remained to support the development of a new government, maintain security, and rebuild a nation.

Canada's Joint Task Force 2 (JTF2), the Canadian special operations unit, launched Operation Apollo under the campaign against terror, Operation Enduring Freedom, that lasted from 2001 to 2003 . Their task was to eliminate the Taliban and al-Qaeda members in Kandahar. In 2002, the Canadian Forces $3^{\text {rd }}$ Battalion, Princess Patricia's Canadian Light Infantry (3 PPCLI), joined the effort to support the stabilization of the area. In 2003, Canada participated in the International Security Assistance Force (ISAF) under Operation Athena, the peace and combat mission, until 2006 and CF served as part of the NATO-led Kabul Multinational, brigade. Operation Archer began in 2006, which had the mission to train the new Afghan National Army and aid in the reconstruction efforts in the Kandahar region of Afghanistan until 2011. From 2011 to 2014, Canada conducted Operation Attention which focused on military support training to support the national security forces of Afghanistan.

The 1960 s to the end of the 1990s marked a period of contraction in the CF in budget and personnel, and there was little development in their public affairs strategy from the 1980s to the beginning of Canada's deployment in Afghanistan. At the time, there was a difficult relationship between the military and media as DND's public image suffered. The poor public image arose from several events. The disbandment of the Canadian Airborne Regiment in 1993 after a Somali teenage boy was murdered at the Canadian base in Somalia and the attempt by the Department of National Defence at a coverup 
which ensued caused also caused alarming public dismay. Furthermore, reports of terrible hazing in the CF, particularly a few stories surfaced about the Airborne Regiment, poor culture, and allegations of sexual abuse confounded the Canadian public.

Public interest in Canada's participation in, what the Pentagon and Bush administration had named the global War on Terror, attracted media attention. Naturally, these warfare activities also quickly garnered the attention of the Canadian public. According to DND public affairs officer (PAO) Don Roy, who eventually penned the CFMEP rules, there was "no official policy for dealing with media in theatre" until 2001, and the CAF had not updated its public affairs strategy in 20 years. ${ }^{105}$ Until 2006, reporters were offered temporary placements upon request. ${ }^{106}$ Prior to that, during Operation Athena, several Canadian journalists were informally embedded at Camp Julien in Kabul. Canadian journalists criticized that often they had very little latitude to report.

Murray Brewster, who had spent the most time in Afghanistan of all Canadian journalists, recalls the follow experience, in his book The Savage War the Untold Battles of Afghanistan (2011). After learning about the death of Pte. Robert Costall, who as journalists would find out days later, had accidentally been killed by friendly fire he wrote the following.

\footnotetext{
105 Price, "Inside the Wire: A Study of Canadian Embedded Journalism in Afghanistan," 40.

106 Price, 40.
} 
It was the first time I actually felt like a hostage of the army. They could tell us as much or as little as they wanted, and they often chose the latter. In this case, they chose to say nothing, or next to nothing, which was probably worse. News, especially big news, abhors a vacuum...[It] was my first experience with how hopelessly and wilfully inarticulate the Canadian military could be. ${ }^{107}$

From another perspective, in capturing the deep emotion, bloodshed, bravery and determination of Canadian troops, journalist Christie Blatchford, chose openly to write in an adversarial manner. Her reporting, and later her book, Fifteen Days: Stories of Bravery, Friendship, Life and Death from Inside the New Canadian Army (2008), is clear about her jingoistic stance. Charles Learmonth, for Esprit de Corps writes: “As one senior Canadian military commander, who wishes to remain anonymous, said of Blatchford and her reporting: "We owned her as soon as she got blood on her boots."“'108

When Ottawa decided to double its efforts to move towards Kandahar in 2006, media interest embedding re-emerged. The CFMEP was established in 2006, raising the total from about 50 to 230 embedded journalists with 40 different media outlets being represented. Amongst embedded reporters were Murray Brewster, Christie Blatchford, Matthew Fisher, Mellissa Fung, Colin Freeze, Brian Hutchinson, Adnan Khan, Michelle Lang, Mitch Potter, David Pugliese, Graeme Smith, Stephen Thorne, and Chris Wattie.

\footnotetext{
${ }^{107}$ Brewster, The Savage War the Untold Battles of Afghanistan , 19.

${ }^{108}$ Learmonth, "Fifteen Days: Stories of Bravery, Friendship, Life and Death from inside the New Canadian Army."
} 
The Canadian embedding program was based on what the Pentagon had instituted in 2003 in Iraq.

The biggest difference between the American and Canadian programs, were that embedded journalists, under the CFMEP, could temporarily dis-embed and re-embed. This meant that journalists could cover non-CF events, leave the supervision of the military and seek local stories without the accompaniment of any force. This is a significant development as it allowed journalists a greater opportunity for independence away from militaristic stories. They could cover local stories and provide for the broadest possible perspective until that time. This characteristic is a major distinguishment between the American embedding program, which did not provide for its journalists to leave the accompaniment of the military. If American journalists chose to do so, they would have to leave the embedding program entirely. The dis-embedding potential that Canadian embedded journalists enjoyed resulted because the CF had a shortage of available vehicles that transported the journalists who accompanied military patrols. ${ }^{109} \mathrm{In}$ dis-embedding, journalists would be required to make their own accommodations, including hiring a driver, a fixer and possibly security. A fixer would have been a local contact who made arrangements for the journalist, often also taking the role of a translator. Once a journalist returned to the operating base, they would once again be held to the embedding rules and guidelines. The structure of the media embedding program and its policies shape the access journalists have to information and how they frame

\footnotetext{
${ }^{109}$ Wasilow, "Contemporary Canadian Military/Media Relations: Embedded Reporting during the Afghanistan War," 139.
} 
stories. Wasilow notes that the reporting of the Afghanistan War- as regarded by military personnel and government officials — lacked coverage of humanitarian efforts. ${ }^{110}$ Dis-embedding or temporarily unembedding, unique to the Canadian Forces, appears to be underexplored and underutilized by Canadian reporters. ${ }^{111}$

As terror tactics and suicide bombings steadily increased, from 2006 onwards, the risk and cost of insurance to send correspondents to Afghanistan became too inordinate for media outlets to sustain. In 2008, CBC journalist Melissa Fung, who was not embedded with the military, was kidnapped and detained for almost a month before negotiations led to her release. In 2009, CBC embedded journalist Michelle Lang was the first Canadian journalist to be killed when a roadside bomb struck an armoured military vehicle, killing four other Canadian soldiers in its blast. Lang's death served to reinforce the idea that although embedding was a safer option, there are no safe ways to cover a war from the frontlines. As Operation Archer pressed forward, the number of embedded journalists steadily decreased. In light of security concerns, those that remained were often forced to stay put in the Kandahar Airfield (KAF). Consequently, and to the frustration of Canadian government officials, ${ }^{112}$ a lot of coverage was dedicated to ramp ceremonies, a memorial service held in the repatriation of fallen soldiers, which were all safer occasions for journalists to report.

\footnotetext{
${ }^{110}$ Wasilow, "Contemporary Canadian Military/Media Relations: Embedded Reporting during the Afghanistan War."

111 Wasilow.

112 Wasilow, 140.
} 
Similar to the American strategies, the Canadian government and the CAF, mischaracterized the UN sanctioned mission as a "keeping the peace" in Kandahar. Early on in the war, Canadian Broadcasting Corporation (CBC) polls found that $80 \%$ of Canadians approved of the mission, however, by $2009,54 \%$ of Canadians wanted the mission to end. ${ }^{113}$ There was no peace to keep, and the Canadian combat missions in Afghanistan "were definitely not peacekeeping." 114 "And independent commission of eminent Canadians tasked with studying the military mission in 2008, in fact, concluded that the government "failed to communicate with Canadian with balance and candour" about the role of rationale for combat operations in Kandahar." 115 The "peacekeeping myth" has been attributed to the elite -government and militaryendorsing the narrative. ${ }^{116}$

\subsection{Conclusion}

This chapter provides the foundation to discuss journalism through the practice of embedded reporting. It highlights how different forms of journalism and delivering information became the new standards that saturated the news media and how technological evolution supported a change in the model of conflict journalism. The

\footnotetext{
${ }^{113}$ DeCillia, "The Contested Framing of Canada's Military Mission in Afghanistan: The News Media, the Government, the Military and the Public," 3; "54\% of Canadians Oppose Afghan Mission: EKOS Poll."

${ }^{114}$ DeCillia, "The Contested Framing of Canada's Military Mission in Afghanistan: The News Media, the Government, the Military and the Public," 3; "54\% of Canadians Oppose Afghan Mission: EKOS Poll."

${ }^{115}$ DeCillia, "The Contested Framing of Canada's Military Mission in Afghanistan: The News Media, the Government, the Military and the Public," 3.

116 DeCillia, 35.
} 
reoccurring pattern is of the efforts by journalists to use proximity to the military and conflict zones to generate coverage that will adequately inform audiences being thwarted again and again by a military preoccupation with control of information, framing and outright censorship. Authority on media and government in the US, and former professor, Steve Hess notes:

[The embedding program was] of the most remarkable win-win-win propositions. It's clear that journalists, who want access more than anything else, were given remarkable access. It seems to be clear that the military got much more favorable coverage than they would have had had there not been embedding. And it's clear that the public saw a type of picture that they had never, never had an opportunity to see before. ${ }^{117}$

The use of the embedding programs in recent Middle-East and Central Asia wars has narrowed the "large gap" 118 between the military, the media and those they serve. From that angle, it is imaginable that an evaluation of modern-day media embedding programs was indeed a "win-win-win." 119 The military benefits from embedding programs to a great extent. They fulfill their legal obligation regarding press access and, by and large, accomplish positive public relations, receiving far fewer press complaints

\footnotetext{
${ }^{117}$ Paul and Kim, "Reporters on the Battlefield: The Embedded Press System in Historical Context," 86; Brookings Institution, “Assessing Media Coverage Of The War In Iraq: Press Reports, Pentagon Rules, And Lessons For The Future," 14.

118 Brookings Institution, “Assessing Media Coverage Of The War In Iraq: Press Reports, Pentagon Rules, And Lessons For The Future," 14-15.

119 Brookings Institution, 13.
} 
than the media management strategies as implemented in Grenada, Panama, and during the first Gulf War. ${ }^{120}$ Paul \& Kim (2005) discern that during OIF, the military was incredibly successful in building its credibility amongst the American public and effectively used press coverage to debunk erroneous claims made by the Iraqi Minister of Information. They also maintain that journalism generated through embedded reporting created favourable conditions to live television. Therefore, television news outlets benefitted in market share, with cable news shows is the preferable source of public information during OIF. ${ }^{121}$ "[Embedding programs have] changed the view of journalists about the military, and maybe in the long run that's more important." 122

Conflict coverage by the practice of embedded reporting undoubtedly gave unprecedented access to journalists. However, as manifested in the American war in Iraq and the Canadian deployment in Afghanistan, modern-day embedding programs required journalists to sign ground-rules agreements that contractually bound them to adhere to rules enforced by the military.

So many of these young journalists had no experience with the military, and probably in a socioeconomic sense where from whence they came, namely, college and professional schools, rather looked down on these grunts who couldn't grow up to be TV anchors and must now think that these people do

\footnotetext{
${ }^{120}$ Paul and Kim, "Reporters on the Battlefield: The Embedded Press System in Historical Context," xviixviii. With notable exceptions being the Vietnam War,

${ }^{121}$ Paul and Kim, 86.

122 Brookings Institution, “Assessing Media Coverage Of The War In Iraq: Press Reports, Pentagon Rules, And Lessons For The Future," 14.
} 
something that's very difficult, things that maybe they couldn't do, and things that are very important. So I hope this was an educational process that worked both ways. $^{123}$

Formal embedding programs were a big win for the news media when compared to the coverage of and cooperation between the military and the media during the US invasion of Grenada and of Panama and during the first Gulf War. Bosnia and Haiti acted as both preludes to cooperation and a proto-embedded press system. ${ }^{124}$

Returning to Kennedy's quote, in the history of conflict reporting, when hurdles and barriers are hurled at journalists, those who pay the price are the journalistic audiences. "In short, the military will control press coverage as it deems necessary or convenient by applying the exceptions and restrictions, and the press will make no serious effort to overcome that by changing its ways. The loser on all counts is the public." 125 The following chapters will explore how media embedding programs unfolding a decade after Kennedy's book was published — might fit in into this statement. An overview of conflict journalism as well as military-media relations, with a focus on Canada, prepares the background to support an evaluation of modern embedding programs and the content they generate in Chapter 2.

\footnotetext{
${ }^{123}$ Brookings Institution, 14.

${ }^{124}$ Paul and Kim, "Reporters on the Battlefield: The Embedded Press System in Historical Context."

${ }^{125}$ Kennedy, The Military and the Media: Why the Press Cannot Be Trusted to Cover a War, 31:158.
} 


\section{Chapter 2: Evaluating Modern Day Embedding Programs and the Content they Generate}

But what conditions are necessary for those who practise journalism to be able to get at the truth, and also to communicate that truth to the public in a way that their citizens will believe it? The answer...is loyalty.

- Kovach and Rosenstiel ${ }^{126}$

\subsection{Introduction}

This chapter reviews several of the common which influences in the news media environment which permeate into the journalism generated. Then, this chapter evaluates modern-day embedding programs in relation to the norms of the journalism industry, the standard of traditional and pragmatic objectivity, and the ability to relay truthful information. It disqualifies traditional objectivity as a criticism of conflict coverage because it is a standard no longer held in the modern news environment.

The chapter uses the American deployment in Iraq and the Canadian mission in Afghanistan as case histories and applies media theory to explain the possible biases that that seep into conflict journalism. Whether or not the embedding programs have impacted the true independence of the journalists by reason that embedded reporters have more contact with senior military commanders and public affairs specialists, there is increased

\footnotetext{
${ }^{126}$ Kovach and Rosenstiel, The Elements of Journalism : What Newspeople Should Know and the Public Should Expect, 71.
} 
speculation the military will exercise influence, however subtle, over what journalists would decide to cover. ${ }^{127}$ As a final note, this chapter agrees with the assessment that conflict journalism generated by the practice of embedded reporting is not the only method of conflict coverage, nor should it be. The breadth of coverage during a conflict is rendered more complete by an aggregation of various reporting methods.

\subsection{Biases}

As noted in Chapter 1, historically, media biases have been intrinsic to conflict coverage because the mass press and governments have employed a great deal of propaganda as a war effort. Furthermore, the structure of the news industry has also evolved over time, morphing, and developing into the present norms. The restructuring of the news media through the process of commercialization in the $19^{\text {th }}$ century changed what was the news media from the dissemination of opinion by an editor for political purposes to the dissemination of news by a large news organization for profit. The news media eventually matured to the point where the press no longer saw itself as a servant of the political aspirations of special interest groups and individuals. However, in the pursuit of a larger audience to meet the circulation and advertising targets, the speed at which news was disseminated was at the expense of accuracy and partisanship. ${ }^{128}$ If the democratic functions of the news media are in its ability to disseminate factual news quickly, in a non-partisan and independent way, then the modern mass press organized in

\footnotetext{
${ }^{127}$ Bergen, "Censorship; the Canadian News Media and Afghanistan: A Historical Comparison with Case Studies."

${ }^{128}$ Ward, Disrupting Journalism Ethics : Radical Change on the Frontier of Digital Media, 181-90.
} 
the form of a social welfare state has re-feudalized journalism, ${ }^{129}$ to such an extent that it was necessary to reconjure the great importance of the citizens which journalism serves.

$[\mathrm{N}]$ ewspaper publishers gradually came to understand in the nineteenth centuryand what generations of news publishers across other technologies refined with significant hardship and later, under duress began to forget in the twentieth-is that those who produce news in an organization (whether the ultimate motive is profit, prestige, community building, authority, audience reach, or some other mix) must have one allegiance above all others. And this commitment forms the second element of journalism: journalism's first loyalty is to citizens. ${ }^{130}$

Several media biases exist in the contemporary news environment. A few obvious ones are listed here. They are listed here to acknowledge that they affect conflict coverage through embedded and unilateral reporting practices. If conflict journalism through embedded and unilateral reporting practises are the variables, the following are confounding factors. It is worth going through them to avoid making spurious associations.

Managers shape editorial material and, by doing so, directly influence how a story should be written, as well as in their hiring decisions and their general editorial policies. Class biases occur because a market-driven editorial policy disproportionally favours the

\footnotetext{
129 Ward, 175.

${ }^{130}$ Kovach and Rosenstiel, The Elements of Journalism : What Newspeople Should Know and the Public Should Expect, 70-71.
} 
needs and tastes of affluent readers. ${ }^{131}$ Cross-media ownership has exacerbated editorial influence possibilities because a single corporate entity can own several newspapers, broadcasts and radio stations. ${ }^{132}$ In Canada, the Special Senate Committee on Mass Media (the Davey Committee) found that the cross-media ownership presented a threat to the quality of the news. ${ }^{133}$ Additionally, the mergers of major news conglomerates narrow the range of viewpoints that are made available to the news consumers. ${ }^{134}$ The framing of news production has slid to the right in that there is less political diversity, ${ }^{135}$ and in Canada, defence is a partisan issue. Lastly, news has an increasing consumerist orientation, focusing on stories such as the price of oil, labour-management conflicts rather than examining the broader social, political and economic forces that animate them. These sorts of stories aim to maximize the potential size of the audience, but in doing so, expunge the differences in each demographic group — in income, age, political leaning. Since advertisers are most interested in specific demographics (those that buy into what they are selling), the people who do not fit into the demographics that the advertisers wish to target are left in an absence.

Equally, foreign correspondents, like all journalists, face non-volitional biases. However, biases do not necessarily implicate wrongdoing. Media theorist, J. Anthony Blair, identifies three types of biases, (1) bias that is bad and avoidable; (2) bias that is unavoidable, potentially dangerous, but for which one can compensate; and (3) bias that

\footnotetext{
${ }^{131}$ Skinner, Cross, and Hackett, "Media Policy Reform as a Foundation for Better Journalism," 78.

132 Skinner, Cross, and Hackett, 80.

133 Senate of Canada Committees, "Special Committee on Mass Media."

${ }^{134}$ Skinner, Cross, and Hackett, "Media Policy Reform as a Foundation for Better Journalism," 83.

135 Skinner, Cross, and Hackett, 78.
} 
is contingent and good—or at least neutral. ${ }^{136}$ Unavoidable bias happens by reason that a journalist has an objective stance and takes a point of view. In the twenty-first-century news model, neutrality plays less of a significant role than the importance of the ability to question one's stance. The stenographic view from above is metaphysically indefensible. It is a journalist's job to critically weigh the relative importance of the events reported, judging the implication of the event as a whole or the significance of particular elements. In making these choices, a journalist automatically engages in their personal biases. Reporters can evaluate whether their bias has any objectionable results or should be challenged in any given case because they are aware that some form of biases exists. In her study, Wasilow finds that the majority of the embedded journalists who participated in covering the Canadian deployment in Afghanistan were cognizant of the limitations and restricted scope of embedded reporting. ${ }^{137}$

While the reporter has more access, more military cooperation, their movements are more restricted than a unilateral reporter. "Correspondents, dependent on soldiers for everything, including their safety, might be vulnerable to emotional bonding that could sway new judgement." ${ }^{n 138}$ Here is where the criticism of embedded journalism is rooted: the scope of embedded reporting is narrowed and often accused of being one-sided because it is limited to government and military matters. ${ }^{139}$ By virtue of the bonds formed

\footnotetext{
${ }^{136}$ Blair, "What Is Bias?," 3.

137 Wasilow, "Contemporary Canadian Military/Media Relations: Embedded Reporting during the Afghanistan War," 209.

${ }^{138}$ Ricchiardi, "Close to the Action," 30.

${ }^{139}$ Ganey, "Mixed Reviews on Embedded Reporters."
} 
in intense environments, the relationship that an embedded reporter might have with the soldiers calls a reporter's objectivity into question.

\subsection{Traditional and Pragmatic Objectivity}

The disputability of a foreign correspondent's ability to be objective is the largest criticism of the journalism generated by the practice of embedded reporting. Yet, the standards of modern journalism do not ask reporters to operate under the traditional definition of objectivity. The Canadian Association of Journalists does not include objectivity as one of its guiding principles for ethical journalism. ${ }^{140}$ It begs the question, of why modern conflict reporting is held to the outdated standards of traditional objectivity, a standard that modern journalism does not hold. Modern journalism asks for pragmatic objectivity where a reporter takes an objective stance but does not aim for the impossibility of neutrality.

Since the norm of objectivity was established in the US at the beginning of the 1920s, countless epistemological conventions have been questioned to substantiate its claim. The requirement of objectivity is regarded as a "moral ideal" or set of practices that define and safeguard the routines of news writing. The characteristics of objectivity are: "impartiality and non-bias, balance and fairness, factuality and detachment are operationalized in routines like separating facts from opinions, only considering

\footnotetext{
${ }^{140}$ CAJ Advisory Committee, "Principles for Ethical Journalism."
} 
something a fact when it is confirmed by various independent sources, attributing quotes and information, hearing both sides in conflicts..."141

While objectivity is a procedure for professional norms, the idea of a journalist as being an uninvolved observer is unobtainable. The practice of journalism is not one of stenography. Instead, it requires executive decision-making about what to include in a story and how it will be done. Ward calls this the difference between traditional objectivity and pragmatic objectivity. Ward argues that traditional objectivity is based on a naïve realism, assuming that an observer passively consumes the facts of the world surrounding them. However, knowledge and inquiry are based on interpretation.

Traditional objectivity was rooted in a misleading metaphor of the journalist as a recording instrument who passively observes and transmits facts. When positivism and its passive model collapsed, so did traditional objectivity.

In the long run, the traditional conception of objectivity would engender futile debate, preventing the construction of a more defensible ideal. As criticism of objectivity arose in academia and in journalism, defenders of objectivity lacked the concepts to adequately defend their view. Debate became focused on the wrong issues; for example, whether journalists could be perfectly objective. Both the defenders and critics of objectivity tended to assume that traditional

\footnotetext{
${ }^{141}$ Peters and Broersma, "Rethinking Journalism: Trust and Participation in a Transformed News Landscape," 32.
} 
objectivity was the only one on offer. It had to be defended, despite its flaws, because the option was flimsy, irresponsible reporting. All of this was occurring as other disciplines were developing richer notions of objectivity that acknowledged knowledge as an interpretive achievement. This turmoil ignored an obvious question: Why is traditional objectivity the only notion under discussion ${ }^{142}$

Pragmatic objectivity, says Ward, removes the distinction between news as objective facts and subjective opinions. Dichotomizing news as either an objectively accurate rendition of fact, or a subjective opinion, creates a false dilemma. In this perspective, news can be considered in a continuum, ranging from commentary to straight reporting. Between the two poles exists a space of complex analysis, wellevidenced commentary that "differ not by an absence or presence of interpretation, but by their degree of interpretation and theorizing." ${ }^{143}$ Ward is suggesting that "the objective stance is not limited to what we call straight reporting." 144 So news can thus, "be evaluated according to the standards of empirical fact and coherence, and so can commentary."145 Ward also offers the concept of the 'objective stance.'

It consists in a number of intellectual virtues such as a willingness to place a critical distance between oneself and the story, to be open to evidence and

\footnotetext{
${ }^{142}$ Ward, Invent. Journal. Ethics Path to Object. Beyond, 145-46.

143 Ward, "Objectivity," 148-49.

${ }^{144}$ Ward, Invent. Journal. Ethics Path to Object. Beyond, 148-49.

${ }^{145}$ Ward, 148-49.
} 
counterarguments, to fairly represent other perspectives, and to be committed to the disinterested pursuit of truth for the public as a whole. One is "disinterested" in not allowing one's interests to prejudge or distort a story. The objective stance requires the integrity to admit error and to recognize blind spots in one's thinking. ${ }^{146}$

Ward's explanation of pragmatic objectivity rather than traditional objectivity eliminates the concern of reporters having to remove one's personal bias and interpretations. Modern-day journalism is not viewed as a practice of reporting facts and thereby leaving the public to judge what is true or false. The model of traditional objectivity has been in decline since the 1950s because it led to a "doctrine distinct from journalistic empiricism." ${ }^{147}$ Reporters would be limited to the role of fact verification rather than analysis. "In sum, trends in journalism and in society threatened the naïve idea that reporters could easily obtain the truth through mere observation." "148 For war reporting, this is especially dangerous because agents in a manipulative public sphere often distort events. For example, PAOs who, as noted in Chapter 1, have historically played a large role in censoring or distorting information. Towards the end of the twentieth century, objectivity was seen as "the tainted dogma of a dominant corporate media, arguing objective routines did little more than protect journalists from criticism." 149

\footnotetext{
146 Ward, 147.

147 Ward, 143.

148 Ward, 143.

149 Ward, 144.
} 
As the twentieth century saw the rise and fall of objectivity, it is possible to see why the practice of embedded journalism has faced so much scrutiny regarding the objectivity of the reporter. While official North American embedding programs did not start until the early twenty-first century, journalists had already long been attached to military units on a less formal agreement. From the viewpoint of traditional objectivity, the practice of embedded journalism is flawed because of the naïve realism where a reporter is expected to stenograph the world around them passively. Secondly, through the commercialization of the press, choices are made with profit consideration, rendering the entire practice of objectivity problematic. And thirdly, an embedded reporter, under the norms of traditional objectivity, subverts its role of holding power to account.

The practice of pragmatic objectivity under a twenty-first-century model, according to Ward, is one of philosophical examination where knowledge is an interpretive achievement. ${ }^{150}$ It is an active, interpretive, cultural activity that does not aim for an absolute projection of reality, instead focuses on a well-grounded inquiry and critical thought. ${ }^{151}$ There is no reason that embedded reporters cannot take this objective stance. A critical distance between oneself and the story is not merely physical. It is also possible that the heightened awareness of the distance between the journalist and the troops he travels with or base he stays on may bring the journalist to recognize and reflect their objective stance. A unilateral reporter, who would typically have a more considerable

\footnotetext{
${ }^{150}$ Ward, "Inventing Objectivity: New Philosophical Foundations," 145.

${ }^{151}$ Ward, 145.
} 
physical distance from the military, might take that distance for granted and pay less consideration to their critical distance.

However, it is not enough to have an objective attitude. One has to apply this attitude to the construction and evaluation of stories by employing criteria of three general kinds: First, criteria that test the stories for correspondence with carefully obtained and collaborated evidence. Second, criteria that test the coherence of claims in the story with existing knowledge and expertise. Third, criteria that test the story for how well it has framed the issues, and whether it has consulted a diversity of perspectives. ${ }^{152}$

On a practical level, the broad standards of an objective stance are translated to specific procedures related to a particular domain, or in this case, a journalistic practice. ${ }^{153}$ Ward gives the example that objectivity for a health researcher might require a design of a triple-blind test. Still, it might require collaborating stories across independent sources or cross-verification to find patterns in the data for a reporter on the health beat. ${ }^{154}$ Pragmatic objectivity does not take the stance that a reporter remains neutral. An embedded journalist engages in pragmatic objectivity, not by being physically removed from a story, but by being committed to the thought that their previous beliefs may be disproven. When placed beside one another, embedded and unilateral journalism would have the same potentiality to employ pragmatic objectivity.

\footnotetext{
152 Ward, 147.

${ }^{153}$ Ward, 147.

${ }^{154}$ Ward, 147.
} 


\subsection{The Ability of Embedded Journalists to Relay the Truth}

In inaccessible or remote parts of the world, journalists and the military hold agenda setting positions to impose information onto the public. Equally essential as the requirement of objectivity is the necessity of credibility and trust and the relationship between journalists and their audiences. Without a trustful relationship, journalism fails its ideal to reinforce democracy. Journalism subverts its role in strengthening democracy when the public good it provides is received with doubt and mistrust. Reporters benefit from the embed program by witnessing dangerous events firsthand, suggesting a clearer sense of the nature of war, bred in a safer space than reporters who travel by themselves. Furthermore, bearing eyewitnesses to events that a unilateral journalist might not be able to access, obliges the journalist to reflect on their own experiences, rather than evaluate the experiences of potential sources. The journalist becomes a source by inserting themselves in action. A foreign correspondent also has more potential to correct the misstatements by stakeholders in the conflict because of their proximity. The traits of the embed programs point to many benefits for both the media and the military. Despite appearances, by embedding with the military, a reporter becomes an agent in the contract that binds them with their host.

Truth in journalistic work is perhaps best described through correspondence theory. In this theory, the truth and falsity of a proclamation are based on how accurately it reflects a measurable reality. Not without its flaws, a correspondence notion of truth is 
one that mirrors an image of reality. The reason correspondence theory works as a journalistic definition of truth is because a journalist can only report on what they experience through their senses. This includes their own senses of seeing, hearing, touch, smelling, and those observations described to them and their ability to reflect and analyze information critically. After all, one can only perceive the existence (whether in its idea or physical presence) of something they care enough about to observe at its outset. In essence, this is one of the debates that Karl Popper, an Austrian-British philosopher (1902-1994), was known for. He argues that observers come with preconceived notions, and thereby he rejected the traditional understanding of the scientific method, dating back to the ancient Greeks. Traditionally, hypotheses were built around observations, confirming one's belief. Popper's scientific method seeks to disconfirm hypotheses in hopes that they will lead closer to believing a truth. Attempting to reject a null hypothesis by disproving all other options requires the practice of pragmatic objectivity because a journalist must remain open to the possibility that they cannot prove their initial explanation of events.

On that premise, there are also policy consequences that limit foreign correspondents from being able to report. The quid pro quo element foreign correspondents being hosted and given unprecedented access to the front lines of war is that they have to sign and abide by ground rules agreements. These are formal policy agreements between the journalist and the military institution that included a list of releasable and non-releasable information under the assertion that the release of sensitive information could cripple operational success. Operational security (OPSEC) as defined 
by the ground rules agreement, during the Canadian operation in Afghanistan included: "specific details on troop strength and equipment, names of military installations or specific geographic locations of military units, information on ISAF or coalition special operations, information regarding force protection measures, and the identity or specialist trades of soldiers who killed or injured anti-coalition militants." ${ }^{155}$ OPSEC limited journalists' access to events, information, and people. The use of OPSEC was at the discretion of the PAO. PAOs are PR-trained media specialists who understand the news media industry and capture journalists' attention. ${ }^{156}$ "PR people will tell journalists what they want them to know—not what they would rather cover up..."157 OPSEC was defined in the ground rules agreement; however, it was often liberally used by the PAO. Many Canadian embedded journalists including, Murray Brewster, the late Matthew Fisher, Paul Watson, Stephen Thorne, David Pugliese, and Scott Taylor, recalled their growing frustration in instances where the PAO or commanding officers denied journalists from reporting because of OPSEC. ${ }^{158}$ Kim \& Paul (2005) observed that during the primary combat operations of OIF, OPSEC was generally intact, being more often protected than violated. OPSEC did not meet the military threshold of "secure," however, neither did they find any evidence that the Iraqi forces took advantage of OPSEC violations. ${ }^{159}$

\footnotetext{
${ }^{155}$ Wasilow, "Contemporary Canadian Military/Media Relations: Embedded Reporting during the Afghanistan War," 138.

${ }^{156}$ Phillips, "Transparency and the New Ethics of Journalism," 373, 380.

${ }^{157}$ Phillips, 380.

${ }^{158}$ Many of their experiences with OPSEC have been recorded in Hobson, "The Information Gap : Why the Canadian Public Doesn't Know More About Its Military.”

${ }^{159}$ Paul and Kim, "Reporters on the Battlefield: The Embedded Press System in Historical Context," 78.
} 
The safeguarding of OPSEC sustains the military's interest in achieving operational success. However, there is a balancing act between the public's right to know and operational success.

There has been a disturbing increase in the military's and the politicians' use of OPSEC claims as a reason for not releasing information to the public and there is a need for a clearer definition of just what constitutes an OPSEC concern. If OPSEC is not redefined and used judiciously, the military will risk its credibility and ultimately the support of the Canadian public. ${ }^{160}$

Ground rule agreements generally do not include an official censorship clause. A censorship clause might consist of formal censorship whereby military personnel have to pre-approve any story before it is sent out for publication. The reasoning behind a standard censorship clause would be to remove all information that might be sensitive to the mission at hand. Its goal is to exclude leaking certain information to the public so that it does not fall into the wrong hands and put the mission at risk. This clause would typically be called a "security review" and is something that neither Canadian nor American ground rules agreement includes.

Instead, the military employs several contentious practises that limit both the access to information by a foreign correspondent and their ability to publish information. Military censorship called "security at the source" as practised within the ground rules

\footnotetext{
${ }^{160}$ Hobson, "Operations Security and the Public's Need to Know," 8.
} 
agreement means that everything said by military personnel is on the record and that it is left to the individual to censor themselves. Security at the source is a form of selfcensorship that places the responsibility of suppressing information on the raconteur, be it the military or the media, to make sure they only release unclassified information to the public. "[E]mbeds avoid the use of specific details in their stories either because the information falls under restrictions dictated by the embed agreement, or because the reporter himself deems the release of information a risk to mission security or soldier's lives." $" 161$

The research by Hobson (2011) and Wasilow (2017) find that most Canadian journalists who embedded during the Canadian deployment in Afghanistan, in general, found their embedding and dis-embedding experience to be a positive one. ${ }^{162}$ However, the difficulty that foreign correspondents faced chiefly regards the distorted use of OPSEC. Brigadier-General Jay Janzen, Director General of Military Strategic Communication for the CAF, observed that members of the media found the ground rules agreement overly restrictive and confusing. ${ }^{163}$ While the Canadian ground rules agreement delineates the information that would need to be suppressed in their reporting, the in-theatre use of OPSEC, as employed by CAF commanders and PAOs, often went beyond its written definition.

\footnotetext{
161 Price, "Inside the Wire: A Study of Canadian Embedded Journalism in Afghanistan," 72.

162 Hobson, "Operations Security and the Public's Need to Know," 6; Wasilow, "Contemporary Canadian Military/Media Relations: Embedded Reporting during the Afghanistan War," 149.

163 Janzen, "Op ATHENA ROTO 0-Embedded Media."
} 


\subsection{Framing}

One approach to qualitatively evaluating media biases, expressly the non-neutral transmission of information, is comparing frames. It is generally agreed that the framing, particularly the way in which a journalist chooses to package a story, differs between conflict coverage through the practice of embedded and unilateral reporting. Framing is "one way the media provides audiences with [the] contextual cues necessary to evaluate the issues under consideration." "164 William Gamson initially defined a frame as "a central organizing idea for making sense of relevant events and suggesting what is at issue."165 Robert Entman added, "To frame is to select some aspects of a perceived reality and make them more salient in a communicating text, in such a way as to promote a particular problem definition, causal interpretation, moral evaluation, and/or treatment recommendation for the item prescribed." 166 Framing defines issues by identifying, evaluating, and then suggesting answers to the underlying forces of a problem. ${ }^{167}$ Journalists make framing decisions in the way they organize information around their existing belief systems, which manifest themselves "by the presence or absence of certain keywords, stereotyped images, sources of information, and sentences that provide thematically reinforcing clusters of facts or judgments." "168 Framing decisions, whether consciously or not, are guiding factors in the conclusions drawn by the receiver. ${ }^{169}$

\footnotetext{
${ }^{164}$ Cooper and Kuypers, "Embedded Versus Behind-the-Lines Reporting on the 2003 Iraq War," 162.

165 Gamson, "News as Framing: Comments on Graber," 157.

166 Entman, "Framing: Toward Clarification of a Fractured Paradigm."

167 Entman.

168 Entman.

169 Entman.
} 
"Framing...plays a major role in the exertion of political power, and the frame in [the] news [media] is really the imprint of power." ${ }^{170}$

By contemplating framing biases, journalists and editors must question their objective stance. Framing is central in the democratic process because it has the potential to shape public opinion. ${ }^{171}$ In this theory, public opinion is malleable by the way in which the news media is framed. Journalists need to treat every source and piece of information as competing frames so that their audiences have a balanced understanding of a situation. When specific frames are highlighted, others might be obscured, leading to a different reaction from the audience. Framing biases compel stakeholders and special interest groups to compete for a dominating frame to shape public discourse. Since foreign correspondents are often some of the only third-party individuals with access to high conflict areas, the way they frame a conflict has a prospective democratic impact. And as noted in many papers, ${ }^{172}$ there is an observable difference between the framing of stories between embedded and unilateral journalists.

\footnotetext{
170 Entman.

${ }^{171}$ Zaller, "The Nature and Origins of Mass Opinion."

172 Johnson, "Perspectives on Iraq War"; Fahmy and Johnson, "Invasion vs Occupation: A Hierarchy-ofInfluences Analysis of How Embeds Assess Influences and Performance in Covering the Iraq War"; Bennett, Lawrence, and Livingston, "When the Press Fails: Political Power and the News Media from Iraq to Katrina."; Wasilow, "Contemporary Canadian Military/Media Relations: Embedded Reporting during the Afghanistan War"; McLaughlin, The War Correspondent; Policy et al., "Reporters on the Battlefield: The Embedded Press System in Historical Context"; Johnson and Fahmy, "When 'good' Conflicts Go Bad: Testing a Frame-Building Model on Embeds' Attitudes toward Government News Management in the Iraq War."
} 
Shanto Iyengar (1991) posited two types of framing. Episodic, being more of an event-based journalism and thematic framing, which resemble backgrounder pieces. ${ }^{173}$ For example, in the Cooper and Kuyper study, the news media generated by embedded journalists more often portrayed Iraqi weakness, desertion or surrender than the journalism created by their unilateral counterparts during the Iraq war. ${ }^{174}$ The articles generated by unilateral reporters displayed more mistrust towards American intentions and anger towards Americans for the destruction caused by warfare. ${ }^{175}$ Journalism developed through the practice of embedded reporting more often showed frames of citizens in celebration after the fall of the Hussein regime where unilateral articles questioned the adequacy of Allied war planning. ${ }^{176}$ Embedded reports described the US invasion as an overwhelming success and exhibited many friendly interactions between the soldiers and Iraqi civilians. ${ }^{177}$ According to Cooper and Kuyper, the differences between the reporting of unilateral and reporters can be accounted by virtue of the journalists' surroundings. Simply put, those who spent more time with the troops recorded the experiences they directly observed, which included more fighting action. In contrast, those at a distance from the action witnessed the uncertainty and unpredictability of war. ${ }^{178}$

\footnotetext{
${ }^{173}$ Is Anyone Responsible? How Television Frames Political Issues.

${ }^{174}$ Fahmy and Johnson, “'How We Performed': Embedded Journalists' Attitudes and Perceptions Towards Covering the Iraq War," 304.

${ }^{175}$ Fahmy and Johnson, 304.

${ }^{176}$ Cooper and Kuypers, "Embedded Versus Behind-the-Lines Reporting on the 2003 Iraq War."

${ }^{177}$ Fahmy and Johnson, “'How We Performed': Embedded Journalists' Attitudes and Perceptions Towards Covering the Iraq War," 304.

${ }^{178}$ Cooper and Kuypers, “Embedded Versus Behind-the-Lines Reporting on the 2003 Iraq War,” 169.
} 
Explanations of the framing differences bring back the questions of objectivity and the ability to tell the truth. Notwithstanding, there are practical and circumspect explanations that can attribute to these differences. For instance, when embedded reporters may be more frequently accompanied by armed military personnel, it commands a consciousness or undercurrent of militancy to locals and civilians. Whereas less threatening individuals would likely accompany a unilateral reporter, a fixer or translator, who are often locals, familiar with the language, the culture, and the conduct of locals. Foreign correspondents who are not embedded have more freedom of movement and latitude towards the civilians they reach.

Wasilow finds that the stories produced by embedded journalists during the Canadian mission in Afghanistan were largely limited to military matters and Canadian soldiers. She determines that Canadian embedded journalists did not make adequate use of the dis-embedding feature of the CFMEP to write stories 'outside the wire,' a quality unique to the Canadian program. The opportunity to dis-embed has the potential to mitigate framing issues that bring about the soda straw effect that focuses journalists' attention on the military. Wasilow finds that the embedded reporters did not take advantage of their capacity to dis-embed because of the influx of inexperienced or underqualified reporters that came into the CFMEP that replaced the experienced reporters who, as a result of the long-standing war, needed respite. ${ }^{179}$ She writes that the structure

\footnotetext{
${ }^{179}$ Wasilow, "Contemporary Canadian Military/Media Relations: Embedded Reporting during the Afghanistan War,” 209.
} 
of CFMEP embed policy led to articles that focused on the military to the detriment of humanitarian efforts. ${ }^{180}$

\subsection{Indexing}

Indexing theory was premised in 1990 by Bennett and later clarified by Bennett, Laurence, and Livingston in 2007 as way to describe media that carries an agenda of elite stakeholders, the politically powerful, and the upper echelons of society. ${ }^{181}$ Indexing explains how most democratic press systems, including legacy press institutions, retain many constructed representation patterns with a "consensus among the elites that somehow reflect the public interest." 182 "Journalists in various national press systems rely on established norms that implicitly filter or "index" the sources and viewpoints in the news according to perceived power balances among factions within political institutions." ${ }^{183}$ Indexing is a democratic issue whereby the press becomes an institution of governance rather than an independent check on those in power. It surfaces by the methodological problems of a journalist who does not seek further analysis in the belief that the source of power from whom they have received information is a comprehensive,

\footnotetext{
${ }^{180}$ Wasilow, 353-82.

${ }^{181}$ Bennett, Lawrence, and Livingston, "When the Press Fails: Political Power and the News Media from Iraq to Katrina."; Bennett, "Toward a Theory of Press-State Relations in the United States."

${ }^{182}$ Bennett, Lawrence, and Livingston, "When the Press Fails: Political Power and the News Media from Iraq to Katrina.," 1.

${ }^{183}$ Lance Bennett, "Indexing Theory," 1.
} 
all-encompassing, and well-rounded understanding. This is what Bill Kovach would consider as the journalism of assertion rather than journalism of verification. ${ }^{184}$

Indexing pertains to conflict coverage in that it was first used to demonstrate how news framing of military conflicts followed divisions in congressional debates in the US. ${ }^{185}$ Bennett's indexing model was also widely confirmed during the Iraq War whereby, despite no credible evidence that Iraq had WMDs, the US administration and the press circulated it as a rationale for their invasion. ${ }^{186}$ As noted in Chapter 1.15 , most Americans initially believed the administration's script. "Similar indexed patterns reappeared in 2004 when most news reports featured government denials that prisoner abuses at the Abu Ghraib prison in Iraq constituted evidence of an illegal policy of torture." ${ }^{187}$ In both cases listed above, the mass press failed its role of being a watchdog. Indexing has most generally been applied to domestic media coverage of foreign affairs. ${ }^{188}$ In 2017, Wasilow did not find indexing to affect the Canadian news reporting of the Afghanistan War. Therefore, no attempt was made to compare the indexing differences between the journalism generated by embedded and unilateral reporting practices. In another study, Brooks DeCillia finds the news media largely indexed its coverage of Canada's military mission in Afghanistan to elite debate.

\footnotetext{
${ }^{184}$ Kovach and Rosenstiel, The Elements of Journalism : What Newspeople Should Know and the Public Should Expect, 106-12.

${ }^{185}$ Zaller and Chu, "Government's Little Helper: U.S. Press Coverage of Foreign Policy Crises, $1945-$ 1991."

${ }^{186}$ More can be found about the Iraq was in Chapter 1.15.

${ }^{187}$ Lance Bennett, "Indexing Theory," 2.

188 Wasilow, "Contemporary Canadian Military/Media Relations: Embedded Reporting during the Afghanistan War," 14.
} 


\subsection{Conclusion}

In this chapter, objectivity was ruled out as a necessary criticism in conflict journalism generated by the practice of embedded reporting. Challenges that lead to news distortions were identified as well as considered media theory as a tool to investigate conflict coverage.

For the mass press, the end result of an embedding program is a system that allowed for unprecedented access to the military operations to a war that ended up being safer for embedded reporters than unilateral ones. During the OIF combat phase, 13 reporters were killed; 4 of these deaths were embedded reporters. ${ }^{189}$ While journalism generated by the practice of embedded journalism was under the set terms of the military, Paul and Kim (2005) found that the press fulfilled its $4^{\text {th }}$ Estate obligations by providing newsworthy information to the public. 190 "While public approval almost certainly results from a variety of factors beyond the issue of whether or not the public receives sufficient information to exercise their democratic rights, approval can reasonably be imputed at least in part from the information's effectiveness in helping people exercise those rights." ${ }^{\prime 191}$ Embedded reporting is but one piece of the puzzle, one method to relay information to the public. When added to the journalism generated by the practice of unilateral reporting, the net result is a far more complete mosaic of the fighting-replete with heroism, tragedy and human error - than would have been possible without embedded reporters. ${ }^{192}$ As

\footnotetext{
189 Paul and Kim, "Reporters on the Battlefield: The Embedded Press System in Historical Context," 84.

190 Paul and Kim, 110.

${ }^{191}$ Paul and Kim, xviii.

192 Ricchiardi, "Close to the Action," 30.
} 
recognized in this chapter, embedded reporting serves the needs of the media, which remain under the thumb of the military. As will be discussed in the following chapter, what is missing in the common considerations and the evaluations of embedded reporting is how the public benefits from conflict journalism through the practice of embedded reporting.

As will be demonstrated, the classical principal-agent problem arises. ${ }^{193}$ Through the process of embedding, a reporter inadvertently becomes an agent of the military, subject to its rules. The asymmetric information sharing and differing interests that exist between the two entities cause both the principal (the military) and the agent (the embedded reporter) to behave contrarily to their mutual loyalties (the public). The military's primary objective is operational success, while that of the press is to provide the information that effective participants need in a democracy. In all cases, those who lose out are the news media consumers.

${ }^{193}$ Paul and Kim, "Reporters on the Battlefield: The Embedded Press System in Historical Context." 


\section{Chapter 3: Working Towards a New Understanding of}

\section{Embedded Journalism}

The embedded press system appears to be the best solution to date at balancing the needs of the three core constituencies (the press, the military, and the public); the questions remain whether that appearance is correct, what improvements remain to be made, and what, if any, vulnerabilities (for any of the constituents) the embedded press system creates.

-Christopher Paul \& James Kim ${ }^{194}$

\subsection{Introduction}

Despite many empirical studies on the impact of embedding on war-time coverage, what appears to be scarcely documented is how the audience perceives the journalism produced by embedded reporters. The key questions that have been asked revolve around the possibility that living and travelling with the troops might influence the reporting. Conversations about the ethics of media embed programs have continued to evolve but the public's perception of journalism generated through media embedding programs is rarely considered in the existing critical reviews.

${ }^{194}$ Paul and Kim, iii. 
The examination of public relations and warfare is well studied because, as predicted by Ray Heibert in 1991,

[P]ublic relations and public communications would play an increasingly significant role in warfare, that the battle for public opinion would be as important as the engagement of soldiers on the front... The examination of the importance of public relations to warfare led to the prediction that, because of expanding communication technologies, wars would be more transparent, and thus cleaner, shorter, and faster. ${ }^{195}$

The willingness of the military to have an embedding program reflects an understanding of the potential for developing public support. ${ }^{196}$ The persuasiveness of an article seems relevant, considering the few parties have access to the frontlines and that one of these parties becomes the standard of truth. Naturally, the democratic value of conflict journalism is in its potential to be the standard of truth set side by side to a public relations campaign.

While this chapter does not seek to explicate conflict coverage through participatory journalism instead, it contends that the drawbacks of other forms of conflict coverage are precisely why this thesis advocates for more transparency in embedded

\footnotetext{
${ }^{195}$ Hiebert, "Public Relations and Propaganda in Framing the Iraq War: A Preliminary Review," 243.

${ }^{196}$ Child and Casper, "Embedded Reporting and Audience Responce in the Iraq War."
} 
journalism. In assessing the efficacy of different methods of covering conflict, more attention ought to be devoted to the needs and reactions of journalistic audiences.

This chapter begins with an expression of the importance of good journalism and its role in democracy. Then it takes a turn to focus on those who the journalism servesnamely the journalistic audiences in the public sphere. Later, this chapter advocates for more transparent conflict journalism and proposes a way to look beyond common criticism of journalism by the practice of embedded reporting that centralizes news consumers.

\subsection{The Public Reliance on Good Journalism}

The democratic functions of the news media are manifested in its ability to disseminate factual news quickly, in a non-partisan and independent way. ${ }^{197}$ Ward (2004) writes that trust in the political-public sphere is attached to the mediums that disseminate public opinion. Trust in the news depends on the public's beliefs about moral, journalistic practices and their ability to cover events accurately. ${ }^{198}$ The democratic value of embedded journalism is that audiences rely on it for a standard of truth. In exploring the core values and methods of journalism, media theorists Elliot and Ozar suggest "making discerning pursuit and effectively disseminating information." 199

\footnotetext{
197 Ward, “Objectivity,” 175.

${ }^{198}$ Ward, Disrupting Journalism Ethics : Radical Change on the Frontier of Digital Media.

${ }^{199}$ Elliott and Ozar, "An Explanation and a Method for the Ethics of Journalism," 16.
} 
Some kinds of information are essential for people to function as a society, and the absence of such information makes it extremely difficult for individuals to work together in groups and for both individuals and groups to give direction to the society and to effect important changes in the society when these are needed. This is the kind of information that both journalists and political theorists have in mind when they talk about journalism as an essential tool for controlling governments' abuses of power and for preserving and growing a democratic society. ${ }^{200}$

The way conflict is covered directs how the conflict is discussed in the political public sphere, as most of the information available to the public is made accessible through media. The discourse then reverberated back onto the media and, as a consequence, reflects the attitudes and norms on human rights, military power, geopolitics, and aggression. ${ }^{201}$ "[C]onflict and suffering have significance in the contexts of particular cultures, that they emerge as meaningful objects in relation to the specific discourses by which we make sense of the world." ${ }^{202}$ Embedded journalism has the potential to strengthen the discourse in the political public sphere. And as journalistic norms and values have changed over the years, so have the formats in which they are disseminated. Embedded war reporting is an essential element in a participatory democracy. It matters because the way journalism is constructed is linked to how journalism is perceived and the value it has in the political-public sphere.

\footnotetext{
200 Elliott and Ozar, 12-13.

${ }^{201}$ Markham, The Politics of War Reporting Authority, Authenticity and Morality.

202 Markham, 1.
} 


\subsection{The Public Perception of Embedded Journalism}

There is very little known about how news consumers perceive conflict coverage practices, and it is likely that most journalistic audiences are not aware of the practice of embedded journalism. If reporters are involved in the story, they disclose their embedded status, but, more often than not, a news consumer would not know or have enough informational cues to deduce how the piece of conflict journalism was produced. Informational cues might lead a reader or viewer to understand that the reporter is in a particular location, perhaps on the frontlines or in a neighbourhood near the conflict. The methodology of news collection and production are implicit. The expectation or standard of sound journalistic practices is connected to the news media outlet or specific journalist through relationships of trust.

In some ways, the relationship of trust between a publishing outlet and its readership can be compared to studies published in academic journals. When reading an academic study, at a quick glance, a reader might start with the introductory section, pass on to the analysis and subsequently the conclusion. The conclusions have some credibility because of the expectation that in order to have been published in a reputable academic journal, the study must have undergone some methodological scrutiny and peer-review. That same expectation, of a certain level of accuracy and reliability, can also be associated with certain legacy media outlets, or whichever news outlets journalistic audiences have made the choice to consume. Whatever they may be, there are always expectations associated with the reputability of the news organizations. When comparing 
a scholarly article to a piece of journalism, the broadcast airtime or word count is substantially shorter for the latter. When stories are subject to short broadcasting time constraints or a limited word count, first come the facts, then come how the facts were obtained. This is why, the relationship of trust between a journalist, a news outlet and their audiences are so important, because seldom is there ever the availability to fully communicate background research and fact-checking practices that confirm the accuracy of the piece of journalism. In standard journalism, a reader would not find a methodology section in which all reporting choices are justified or at least explained the reasons for which they were made.

Public understanding of the practice of embedded journalism programs is not an issue of disclosure or convoluting unsound reporting methods; it is about consumer appetite. There is simply rarely enough time or space in a piece of journalism to cover the methodological choices, while keeping consumer attention and keeping the piece to a size that makes it possible for an audience to ingest multiple stories in a limited time span. Not to mention, if every news piece written by an embedded reporter explained the practice of embedded journalism as a method of conflict coverage, it might be repetitive and superfluous.

At the same time, should a news consumer become aware that the journalist who is covering a conflict is being fed, housed, transported, and kept safe by a military institution - one that they are expected to cover - it could be supposed by the news 
consumer that there are issues of independence and objectivity. ${ }^{203}$ This is why there needs to be more of a consideration towards the needs of an audience or their reactions when assessing the efficacy of different methods of covering conflict.

Chapter 2 addresses the common criticisms of embedded journalism. In modern journalism, perhaps the standard of objectivity, as it is traditionally viewed, is moot. Present-day objectivity in journalism, or pragmatic objectivity, as media theorist Stephen Ward names it, does not require a journalist to take a neutral stance. Pragmatic objectivity considers the truth as disclosed by biases or sentiment on a subject. The practice of objectivity in $21^{\text {st }}$-century journalism is based on an active, interpretive, cultural activity that does not aim for an absolute projection of reality, instead of focusing on a wellgrounded inquiry and critical thought. ${ }^{204}$ The notion of pragmatic objectivity in modern journalism, although well accepted in the journalism industry and by communication scholars, objectivity is perhaps erroneously understood by news consumers to its traditional definition. It is for such reason that the journalism industry has to maintain a high level of transparency in its methodology. Transparency is essential so that even if a reader is not aware of conflict coverage by the practice of embedded reporting or perhaps has a less nuanced understanding of pragmatic objectivity, the journalist's stance is still understood.

\footnotetext{
${ }^{203}$ A broader discussion on traditional and pragmatic objectivity is offered in chapter 2.3.

${ }^{204}$ Ward, "Inventing Objectivity: New Philosophical Foundations," 145.
} 


\subsection{Transparency}

Trust in the news media is based on the understanding that a journalist and news agency are reporting accurately and ethically, such that the reporting is rooted in truthtelling. This procedural habit backs the reputation of sound reporting conventions in a relationship between the news consumers and the news media. When the relationship is tested, the news media can advocate for the quality of their journalism by operating with transparency. However, in the digital age, "speed is considered to be more important than painstaking fact checking" motivating accuracy sincerity to reside in transparency."205

Embedded reporting is just one way of covering a conflict, and technology advancements in the 21-century have allowed for previously unheard voices to enter the news conversation. The internet, particularly social media, has lifted the monopoly that legacy news outlets have had in exclusively covering a conflict. Facebook, TikTok, WhatsApp, Twitter, Instagram, and YouTube have been utilized in modern conflict as methods of political mobilization and a method of circulating minority voices and citizen journalism in the political-public sphere. The role of journalists as the sole organ of the news has primarily evolved to include participant journalism online. Participant voices challenge traditional practices, creating a more inclusive journalism. ${ }^{206}$ They have served to decentralize power from legacy news media institutions, the government, and military organizations to citizens. ${ }^{207}$ The dissemination of citizen journalism via social media also

\footnotetext{
205 Phillips, "Transparency and the New Ethics of Journalism," 379.

${ }^{206}$ Witschge, "Transforming Journalistic Practice: A Profession Caught Between Change and Tradition," 167.

${ }^{207}$ Patrikarakos, War in 140 Characters: How Social Media Is Reshaping Conflict in the Twenty-First Century.
} 
has the potential to disrupt propaganda narratives or create propaganda narratives of their own. "Bloggers see truth as work in progress. They will publish rumours and wait for readers to react to them, believing that the interactivity of the Web will provide its own corrective." 208

The TikTok intifada used to publicize the Palestinian narrative is a recent example of the use of social media in conflict coverage during the Israel-Hamas 11-day conflict from May 9, 2021, to May 20, 2021. Solidarity videos published through TikTok and Twitter were used to organize international protests, posting videos to Instagram of the destruction and violence in Gaza. ${ }^{209}$ Citizen journalism may not carry the same level of trust that an established reporter and legacy news outlet have previously established. According to the Pew Research Centre, over the past several years, American news consumers consider social media news to be increasingly inaccurate. ${ }^{210}$ Furthermore, Americans did not find that news disseminated via social media increased their understanding of current events. ${ }^{211}$

The elements that empower participatory journalism as a dominant method of disseminating information also contribute to its degradation. Namely, that the participants in such journalism are not bound by ethical guidelines and fact checking standards that lead news consumers to trust the information and analysis being presented in the

\footnotetext{
208 Phillips, "Transparency and the New Ethics of Journalism," 279.

${ }^{209}$ Ward, "Palestinians Are Making Their Case against Israel on Social Media."

${ }^{210}$ Shearer and Mitchell, "News Use Across Social Media Platforms in 2020."

211 Shearer and Mitchell.
} 
traditional news media. The hypothetical gateway of journalism is opened to everybody, including the actors that traditional journalism aims to remove through practices of verification.

Democratizing the dissemination of information by participatory journalism is indispensable to the practice of conflict coverage. Modern ways of conflict coverage by means of participatory journalism have varying levels of transparency in the methodology of news gathering and analysis. It is not an inability on the side of a citizen journalist to recognize inconsistencies and contradictions in the information they receive. However, "[m]ost information circulating is doing so precisely because those responsible for it want people to know about it." 212 While both the journalism generated by journalists and bloggers can unavoidably be manipulated, newsrooms are better positioned than bloggers to carry the financial burden of verifying information. "Organizations seeking publicity have always looked for ways to simplify the circulation of information to the public and news organizations are happy to share sources of routine news." ${ }^{213}$ The military success of an embedding program is a case in point. It is unarguable that embedding programs fostered a positive public image of the militaries who employed them. Philips suggests elevating transparency as a standard of journalism to bolster the entire discipline. "[E]stablishing new standards of transparency could help protect reporting in the new, networked area, as well as improving ethical standards in

\footnotetext{
212 Phillips, "Transparency and the New Ethics of Journalism," 273.

213 Phillips, 273.
} 
journalism. ${ }^{214}$ Likewise, transparency in the domain of conflict reporting would benefit the relationship of trust that exists between the news media and news consumers.

\subsection{Moving beyond Common Criticism of Embedded Reporting}

In 2009, M.F. Casper and Jeffery Child published an article called "Embedded Reporting and Audience Response: Parasocial Interaction and Perceived Realism in Embedded Reporting from the Iraq War on Television News" to test the viewer responses between the newscast produced by embedded and unilateral reporters. This is the only known study that attempts to measure how the embedded format of conflict coverage may affect audience perceptions of information differently than the unilateral format. ${ }^{215}$ Previous studies sought to identify the difference (in tone, breadth, depth, subject) between conflict reporting practices. Other studies undertook to examine how the embedded and unilateral reporters perceived their work and independence.

Casper and Child (2009) found that individuals who watched the embedded newscast report awarded it higher levels of realism than individuals who watched the traditional newscast reports. News consumers also experienced significantly stronger parasocial affinity of the embedded television reporter than the traditional television reporter. Parasocial interactions describe how media consumers develop a relationship with media personas. ${ }^{216}$ In the Casper and Child study, indicates that the news consumers

\footnotetext{
214 Phillips, 273.

${ }^{215}$ Child and Casper, "Embedded Reporting and Audience Responce in the Iraq War," 209.

${ }^{216}$ Horton and Wohl, "Mass Communication and Para-Social Interaction."
} 
felt a stronger perception of a relationship or imagined intimacy between themselves and the embedded reporter. General attitudes towards the news credibility and the viewing habits of respondents were controlled to reflect that the perception of realism and parasocial interaction was related to the clips viewed itself, rather than reflecting participants' existing predispositions towards television news reports. ${ }^{217}$ "Therefore, the current study allows us to move beyond common criticism of embedded television news reports...to a deeper understanding of the mechanisms of television media influence which may be why distrust abounds for the embedded television news reporting style." ${ }^{218}$

There are several limitations in the Casper and Child study. Eighty-four percent of the total sample were between the ages of 18 to 30 , representing a relatively young audience and limiting the results to an adolescent and young-adult population. The limited nature of only using two television reports may have affected viewer's interaction. Child and Casper suggest using longer or multiple clips for examination. The study was conducted in 2009, using news broadcasting media clips from 2003. While both clips dealt with similar content, the study took place six years after the initial broadcast of the media clips. This is significant because, by 2008, President Bush agreed to a withdrawal of U.S. combat troops. The Hussein government fell in 2003, and by 2006 an Iraqi government had been re-established. The news media significantly covered these events. There is a high possibility that the survey participants would have been aware of the war's development between the clip they viewed and the outcomes and events in Iraq since

\footnotetext{
217 Child and Casper, "Embedded Reporting and Audience Responce in the Iraq War."

${ }^{218}$ Child and Casper, 216-17.
} 
2003. Having known the results and significant developments that would have taken place after 2003 (the year the selected news clips were broadcasted) may have also affected the viewer interaction. While Casper and Child controlled television viewing habits, testing viewer interactions of a six-year-old news clip might indicate the biases that news viewers developed between the time the news clip aired and the time the study took place. It is possible that the respondent's reaction confirms already established opinions of the war as opposed to a study between embedded and unilateral reporting formats. Pre-existing perceptions affect the beliefs and interpretation of the content that journalistic audiences receive. For this reason, it is too late to re-run this study or perform a similar study using television segments from embedded and unilateral reporters from the Canadian deployment in Afghanistan.

However, the Casper and Child study suggests that an area that deserves more attention and research could be in understanding how conflict journalism by practices of embedded and unilateral reporting influences news media consumers. While Casper and Child focus on the modality of television, a concentration on new media is equally relevant and might influence the future of conflict journalism.

\subsection{Conclusion}


Conflict journalism by the practice of embedded reporting in North American militaries is expected to last. ${ }^{219}$ Wasilow attributes the longevity of the practice to several reasons; (1) a revenue-oriented news media industry garners attention by engaging in public interests such that war coverage sells; (2) conflict coverage by the practice of embedded reporting has given journalists an unprecedented access to the frontlines and has been the safest method to do so; (3) the novelty of the CFMEP allows for journalists to disembed and re-embed in a manner that can mitigate common issues around the independence of journalists and their ability to cover a wider breadth of the conflict; (4) the Canadian military is highly aware of the benefits to their public image that stems from conflict coverage by the practice of embedded reporting. ${ }^{220}$

The practice of embedded reporting can relieve some of the drawbacks of other reporting practices. Embedding should continue to supplement other systems that provide access to information in striving for extensive and robust conflict coverage. Conflict journalism will likely follow the industry trends such as the news media following the format of digital platforms. Currently, $86 \%$ of U.S. adults get their news via a smartphone, with news websites being the preferred way to get digital news. ${ }^{221}$ Those aged 18-29 are more likely to get news via social media. ${ }^{222}$ The journalism generated

\footnotetext{
${ }^{219}$ Wasilow, "Contemporary Canadian Military/Media Relations: Embedded Reporting during the Afghanistan War"; Price, "Inside the Wire: A Study of Canadian Embedded Journalism in Afghanistan"; Hurley, Turning around a Supertanker: Media-Military Relations in Canada in the CNN Age; Paul and Kim, "Reporters on the Battlefield: The Embedded Press System in Historical Context"; Brookings Institution, "Assessing Media Coverage Of The War In Iraq: Press Reports, Pentagon Rules, And Lessons For The Future."

${ }^{220}$ Wasilow, "Contemporary Canadian Military/Media Relations: Embedded Reporting during the Afghanistan War," 399.

221 Shearer and Mitchell, "News Use Across Social Media Platforms in 2020."

222 Shearer and Mitchell.
} 
through the practice of embedded reporting may see changes to fit the modalities of emerging technology best.

This thesis explores the history of conflict coverage and evaluates the common criticism of modern conflict coverage by the practice of embedded journalism. While the practice of media embedding with the military has trailed off in recent years - in large part in tandem with a reduction in Canada's overseas deployments - it is still important to examine this issue to better inform the next iteration of military embedding. By ruling out objectivity as the paramount criticism of conflict coverage through the practice of embedded reporting, this thesis suggests, that conflict journalism should not be discredited by the fallen, traditional norms of objectivity. Future analysis of conflict journalism could be more result oriented rather than process oriented, in that it considers reader's reaction to the journalism, as a result, rather than the journalism produced as a final product. It could place a stronger focus on news audiences in addition to the already widely analyzed area, of how a reporters' environment in a conflict affects the journalism produced. Finally, this thesis suggests a new avenue to explore, one that primarily focuses on the news consumer rather than on the embedded journalism or the embedding programs themselves. Examining an audiences' interpretation of embedded journalism may help generate a better understanding of civil-and-media-military relations and the role of public support in diplomacy and the policy processes. 


\section{Bibliography}

"54\% of Canadians Oppose Afghan Mission: EKOS Poll." CBC News, June 16, 2009. https://www.cbc.ca/news/canada/54-of-canadians-oppose-afghan-mission-ekos-poll1.859617.

Abrams, Herbert L. "Weapons of Miller's Descriptions." Bulletin of the Atomic Scientists 60, no. 4 (2004): 56-64. https://doi.org/10.1080/00963402.2004.11460804.

Aday, Sean, Steven Livingston, and Maeve Hebert. "Embedding the Truth: A CrossCultural Analysis of Objectivity and Television Coverage of the Iraq War." Harvard International Journal of Press/Politics 10, no. 1 (2005): 3-21. https://doi.org/10.1177/1081180X05275727.

Anam Khan, Shahedul. "The Media and the Military." The Daily Star Web Edition, May 3, 2007. http://archive.thedailystar.net/2007/05/03/d70503150198.htm.

Andrews, J Cutler. "The Southern Telegraph Company, 1861-1865: A Chapter in the History of Wartime Communication." The Journal of Southern History 30, no. 3 (1964): 319-44. https://doi.org/10.2307/2204837.

Baker, Ken. "The Crimean War and the Freedom of the Press." Schools-History.com, February 4, 2009. https://kenbaker.wordpress.com/2009/02/04/the-crimean-war-andthe-freedom-of-the-press/.

Barstow, David. "Behind TV Analysts, Pentagon's Hidden Hand." The New York Times. April 20, 2008. https://www.nytimes.com/2008/04/20/us/20generals.html.

Basen, Ira. "Why Canadian Media Embraced Censorship during WWI." CBC News, August 1, 2014. https://www.cbc.ca/news/why-canadian-media-embracedcensorship-during-wwi-ira-basen-1.2722786.

Bennett, W. Lance. "Toward a Theory of Press-State Relations in the United States." Journal of Communication 4, no. 2 (1990): 103-25.

Bennett, W. Lance, Regina G. Lawrence, and Steven Livingston. "When the Press Fails: Political Power and the News Media from Iraq to Katrina.," 2007. https://doi.org/10.1017/S153759270999168X.

Bergen, Robert. "Censorship; the Canadian News Media and Afghanistan: A Historical Comparison with Case Studies." Calgary Papers in Military and Strategic Studies, no. 3 (2009).

Bethune, Brian. "THE GHOST OF A MAN I NEVER KNEW.” Macleans, August 27, 2007. https://archive.macleans.ca/article/2007/8/27/the-ghost-of-a-man-i-neverknew.

Blair, J. Anthony. "What Is Bias?” Argumentation Library 21, no. 3 (2012): 23-32. https://doi.org/10.1007/978-94-007-2363-4_3.

Brewster, Murray. The Savage War the Untold Battles of Afghanistan . Mississauga, Ont: J. Wiley \& Sons Canada, 2011.

Brookings Institution. "Assessing Media Coverage Of The War In Iraq: Press Reports, Pentagon Rules, And Lessons For The Future," 2003.

CAJ Advisory Committee. "Principles for Ethical Journalism." Canadian Association of Journalists, June 2011. https://caj.ca/ethics-guidelines.

Child, Jeffery, and M.F. Casper. "Embedded Reporting and Audience Responce in the Iraq War." In War and the Media: Essays on News Reporting, Propaganda and Popular Culture, edited by P. M. Haridakis, B. S. Hugenberg, and S. T. Wearden, 
205-21. McFarland \& Company, 2009.

Cook, Tim. "Documenting War and Forging Reputations: Sir Max Aitken and the Canadian War Records Office in the First World War." War in History 10, no. 3 (2003): 265-95. https://doi.org/10.1191/0968344503wh271oa.

Cooper, Stephen D, and J.A. Kuypers. "Embedded Versus Behind-the-Lines Reporting on the 2003 Iraq War." R.D. Berenger Global Med (2004): 161-72.

, Brooks. "The Contested Framing of Canada's Military Mission in Afghanistan: The News Media, the Government, the Military and the Public." London, 2010. http://www.lse.ac.uk/collections/media@lse/mediaWorkingPapers/.

Defence, Department of. "Public Affairs Guidance (PAG) on Embedding Media," 2006. https://fas.org/sgp/othergov/dod/embed.pdf.

WarMuseum.ca. "Democracy at War - Information, Propaganda, Censorship and the Newspapers." Accessed June 20, 2021. https://www.warmuseum.ca/cwm/exhibitions/newspapers/information_e.html.

Elliott, Deni, and David Ozar. "An Explanation and a Method for the Ethics of Journalism.” Journalism Ethics: A Philosophical Approach, 2010. https://doi.org/10.1093/acprof:oso/9780195370805.003.0001.

Entman, Robert M. "Cascading Activation: Contesting the White House's Frame After 9/11." Political Communication 20, no. 4 (2003): 415-32. https://doi.org/10.1080/10584600390244176.

_ . "Framing: Toward Clarification of a Fractured Paradigm." Journal of Communication 43, no. 4 (1993): 51-58. https://doi.org/10.1111/j.14602466.1993.tb01304.x.

Fahmy, By Shahira, and Thomas J Johnson. "Embedded and Perceptions Towards Covering the Iraq War," no. 2 (2015): 301-17.

Fahmy, Shahira. "Picturing Afghan Women: A Content Analysis of AP Wire Photographs During the Taliban Regime and after the Fall of the Taliban Regime." The International Communication Gazette 66, no. 2 (2004): 91-112. https://doi.org/10.1177/0016549204041472.

Fahmy, Shahira, and Thomas J. Johnson. "Invasion vs Occupation: A Hierarchy-ofInfluences Analysis of How Embeds Assess Influences and Performance in Covering the Iraq War." International Communication Gazette 74, no. 1 (2012): $23-$ 42. https://doi.org/10.1177/1748048511426988.

Fahmy, Shahira, and Thomas J Johnson. "'How We Performed': Embedded Journalists' Attitudes and Perceptions Towards Covering the Iraq War." Journalism \& Mass Communication Quarterly 82, no. 2 (2005): 301-17. https://doi.org/10.1177/107769900508200205.

Fialka, John J. Hotel Warriors: Covering the Gulf War. Washington: oodrow Wilson Center Press and Johns Hopkins University Press, 1992.

Foot, Richard. "Somalia Affair." In The Canadian Encyclopedia, November 5, 2018. https://www.thecanadianencyclopedia.ca/en/article/somalia-affair.

Gamson, William A. "News as Framing: Comments on Graber." The American Behavioral Scientist (Beverly Hills) 33, no. 2 (1989): 157-61. https://doi.org/10.1177/0002764289033002006.

Gamson, William A., and Shanto Iyengar. Is Anyone Responsible? How Television Frames Political Issues. Contemporary Sociology. Vol. 21. American Politics and 
Political Economy Series. Chicago: University of Chicago Press, 1992.

https://doi.org/10.2307/2075856.

Ganey, Terry. "Mixed Reviews on Embedded Reporters." The St. Louis Journalism Review 34, no. 263 (2004): 25.

Gerbner, George. "Persian Gulf War, The Movie." In Triumph of the Image: The Media's War in the Persian Gulf-A Global Perspective, edited by Hamid Mowlana, George Gerbner, and Herbert I Schiller, 243-65. Westview Press, 1992.

Gilchrist, Mark. "Why Thucydides Still Matters." The Strategy Bridge, November 30, 2016. https://thestrategybridge.org/the-bridge/2016/11/30/why-thucydides-stillmatters.

Griffin, Megan. “Jane McManus Storm Cazneau, 1807-1878.” Legacy (Amherst, Mass.) 27, no. 2 (2010): 416-32. https://doi.org/10.5250/legacy.27.2.0416.

Haigh, Michel M., Michael Pfau, Jamie Danesi, Robert Tallmon, Tracy Bunko, Shannon Nyberg, Bertha Thompson, et al. "A Comparison of Embedded and Nonembedded Print Coverage of the U.S. Invasion and Occupation of Iraq." Harvard International Journal of Press/Politics 11, no. 2 (2006): 139-53. https://doi.org/10.1177/1081180X05286041.

Henrichsen, Jennifer, and Joanne M. Lisosky. War on Words: Who Should Protect Journalists? Praeger, 2011.

Hiebert, Ray Eldon. "Public Relations and Propaganda in Framing the Iraq War: A Preliminary Review.” Public Relations Review 29, no. 3 (2003): 243-55. https://doi.org/10.1016/S0363-8111(03)00047-X.

Hobson, Sharon. “Operations Security and the Public's Need to Know." Canadian Defence \& Foreign Affairs Institute March (2011).

—. "The Information Gap : Why the Canadian Public Doesn' t Know More About Its Military." Canadian Defence \& Foreign Affairs Institute. Calgary, Canada, 2007.

Horton, D, and R. R. Wohl. "Mass Communication and Para-Social Interaction." Psychiatry: Journal for the Study of Interpersonal Processes 19 (1956): 215-29. https://psycnet.apa.org/record/1957-06011-001.

Hurley, Daniel Terrance. Turning around a Supertanker: Media-Military Relations in Canada in the CNN Age. ProQuest Dissertations and Theses, 2000. https://ezproxy.royalroads.ca/login?url=https://search.proquest.com/docview/30460 1635? accountid=8056\%0Ahttps://royalroads.on.worldcat.org/atoztitles/link?sid=Pro $\mathrm{Q}: \& i s s n=\&$ volume $=\&$ issue $=\&$ title $=$ Turning + around $+\mathrm{a}+$ supertanker $\% 3 \mathrm{~A}++$ Media military+relations + in + Can.

Jacobson, Susan. "Transcoding the News: An Investigation into Multimedia Journalism Published on Nytimes.Com 2000-2008." New Media \& Society 14, no. 5 (January 9, 2012): 867-85. https://doi.org/10.1177/1461444811431864.

Janzen, J. "Op ATHENA ROTO 0-Embedded Media.” The Canadian Army Journal 7, no. 3-4 (2004): 43.

Johnson, Thomas J., and Shahira Fahmy. "When 'good' Conflicts Go Bad: Testing a Frame-Building Model on Embeds' Attitudes toward Government News Management in the Iraq War." International Communication Gazette 72, no. 6 (2010): 521-44. https://doi.org/10.1177/1748048510369217.

Johnson, Thomas J. "Perspectives on Iraq War" 28, no. 3 (2007): 98-115.

Kennedy, William V. The Military and the Media: Why the Press Cannot Be Trusted to 
Cover a War. Choice Reviews Online. Vol. 31. Westport, Conn: Praeger, 1994. https://doi.org/10.5860/choice.31-5852.

Keshen, Jeff. Propaganda and Censorship During Canada's Great War. Edmonton: University of Alberta Press, 1996.

Knightley, Phillip. The First Casualty : From the Crimea to Vietnam : The War Correspondent as Hero, Propagandist, and Myth Maker. 1st ed. New York:

Harcourt Brace Jovanovich, 1975.

Kovach, Bill., and Tom. Rosenstiel. The Elements of Journalism : What Newspeople Should Know and the Public Should Expect. Edited by Tom Rosenstiel. 1st rev. e. New York: Three Rivers Press, 2007.

Lance Bennett, W. "Indexing Theory." Hoboken, NJ, USA: John Wiley \& Sons, Inc, 2015. https://doi.org/10.1002/9781118541555.wbiepc180.

Learmonth, Charles. "Fifteen Days: Stories of Bravery, Friendship, Life and Death from inside the New Canadian Army." Esprit de Corps. S.R. Taylor Publishing, 2007.

Local, Reporting. "Journalists in Iraq : A Survey of Reporters on the Front Lines," 2003, $1-44$.

Markham, Tim. The Politics of War Reporting Authority, Authenticity and Morality. New York: Distributed to the United States exclusively by Palgrave Macmillan, 2011.

Markovits, Stefanie. 'Rushing into Print: 'Participatory Journalism' during the Crimean War." Victorian Studies 50, no. 4 (2008): 559-86. https://doi.org/10.2979/VIC.2008.50.4.559.

Mathews, Joseph J. “THE FATHER OF WAR CORRESPONDENTS.” The Virginia Quarterly Review 21, no. 1 (1945): 111-27.

McLaughlin, Greg. "Goodbye Vietnam Syndrome: The Embed System in Afghanistan and Iraq." Pluto Press, 2016.

—. The War Correspondent. Pluto Press. 2nd ed. London: Pluto Press, 2016. https://doi.org/10.4324/9780203133620-1.

Mordan, Capt Jon. "Press Pools , Prior Restraint and the Persian Gulf War," 1999.

Murray, Larry. "The Faces of Somalia." Maclean's, July 14, 1997. https://archive.macleans.ca/article/1997/7/14/the-faces-of-somalia.

Nash, William L. "The Military and the Media in Bosnia." The Harvard International Journal of Press/Politics 3, no. 4 (1998): 131-35. https://doi.org/10.1177/1081180X98003004013.

Patrikarakos, David. War in 140 Characters: How Social Media Is Reshaping Conflict in the Twenty-First Century. New York: Basic Books, 2017.

Paul, Christopher, and James J. Kim. "Reporters on the Battlefield: The Embedded Press System in Historical Context." Choice Reviews Online 42, no. 11 (2005). https://doi.org/10.5860/choice.42-6314.

Pearson, Lionel. "Thucydides as Reporter and Critic." Transactions and Proceedings of the American Philological Association 78 (1947): 37. https://doi.org/10.2307/283481.

Peters, Chris, and Marcel Jeroen Broersma, eds. "Rethinking Journalism: Trust and Participation in a Transformed News Landscape." In Rethinking Journalism: Trust and Participation in a Transformed News Landscape, 1-252. New York: Routledge, 2013. https://doi.org/10.4324/9780203102688.

Phillips, Angela. "Transparency and the New Ethics of Journalism." Journalism Practice 
4, no. 3 (August 1, 2010): 373-82. https://doi.org/10.1080/17512781003642972.

Policy, Child, Civil Justice, National Security, Public Safety, and Homeland Security. "Reporters on the Battlefield: The Embedded Press System in Historical Context." Choice Reviews Online 42, no. 11 (2005): 42-6314-42-6314.

https://doi.org/10.5860/choice.42-6314.

Ponsonby, Arthur. Falsehood in War-Time, Containing an Assortment of Lies Circulated Throughout the Nations During the Great War. US: Institute for Historical Review, 1928.

Price, Dominique L. "Inside the Wire: A Study of Canadian Embedded Journalism in Afghanistan," 2009.

Price, Vincent. "Social Identification and Public Opinion: Effects of Communicating Group Conflict." The Public Opinion Quarterly 53, no. 2 (June 18, 1989): 197-224. http://www.jstor.org/stable/2749523.

Ricchiardi, Sherry. "Close to the Action." American Journalism Review 25, no. 4 (2003): $28-35$.

Rich, Janine. "'Saving' Muslim Women: Feminism, U.S Policy and and the War on Terror." International Affairs Review, 2014.

Rodgers, James. Reporting Conflict . Journalism: Critical Practice. Houndmills, Basingstoke, Hampshire ; Palgrave Macmillan, 2012.

Roth, Mitchel P. Historical Dictionary of War Journalism. Edited by James Stuart Olson. Westport, Conn: Greenwood Press, 1997.

Schechter, Danny. Embedded--Weapons of Mass Deception : How the Media Failed to Cover the War in Iraq . Weapons of Mass Deception. Amherst, N.Y: Prometheus Books, 2003.

Senate of Canada Committees, 28th Parliament, 2nd Session. "Special Committee on Mass Media." Ottawa, 1969. https://parl.canadiana.ca/view/oop.com_SOC_2802_5_4/1?r=0\&s=1.

Shearer, Elisa, and Amy Mitchell. "News Use Across Social Media Platforms in 2020." Washington, January 12, 2020. https://www.journalism.org/2021/01/12/news-useacross-social-media-platforms-in-2020/.

Skinner, David, Kathleen Cross, and Robert A. Hackett. "Media Policy Reform as a Foundation for Better Journalism." In Journalism in Crisis: Bridging Theory and Practice for Democratic Media Strategies in Canada, 77-100. Toronto ; Buffalo ; London: University of Toronto Press, 2016. http://files/552/Gasher et al. - 2016 Journalism in crisis bridging theory and practice.pdf.

Sylvester, Judith L. Reporting from the Front: The Media and the Military. Edited by Suzanne. Huffman. Lanham, MD: Rowman \& Littlefield, 2004.

Thompson, Eric. "Canadian Warcos in World War II: Professionalism, Patriotism and Propaganda.” Mosaic (Winnipeg) 23, no. 3 (1990): 55-72.

Thucydides, and John Finley. Complete Writings of Thucydides : The Peloponnesian War. Edited by John H (John Huston) Finley. New York: Modern Library., 1951.

Ward, Alex. "Palestinians Are Making Their Case against Israel on Social Media." Vox News, May 20, 2021. https://www.vox.com/22436208/palestinians-gaza-israeltiktok-social-media.

Ward, Stephen J. A. Disrupting Journalism Ethics : Radical Change on the Frontier of Digital Media. Disruptions: Studies in Digital Journalism. London ; Routledge, 
2019.

. "Inventing Objectivity: New Philosophical Foundations." In Journalism Ethics: A Philosophical Approach, 49-59, 1962. https://doi.org/10.5840/stauglect19623.

_. "Objectivity." In Journalism Ethics : A Philosophical Approach. Practical and Professional Ethics Series. New York: Oxford University Press, 2010.

- The Invention of Journalism Ethics : The Path to Objectivity and Beyond. The Invention of Journalism Ethics : The Path to Objectivity and Beyond. Second edi. McGill-Queen's Studies in the History of Ideas ; 38. Montreal [Quebec] ; McGillQueen's University Press, 2015.

Wasilow, Sherry Marie. "Contemporary Canadian Military/Media Relations: Embedded Reporting during the Afghanistan War," 2017.

-. "View of Hidden Ties That Bind: The Psychological Bonds of Embedding Have Changed the Very Nature of War Reporting." Stream: Interdisciplinary Journal of Communication 4 (2011).

http://journals.sfu.ca/stream/index.php/stream/article/view/65/40.

Witschge, Tamara. "Transforming Journalistic Practice: A Profession Caught Between Change and Tradition." In Rethinking Journalism: Trust and Participation in a Transformed News Landscape. New York: Routledge, 2013.

Zaller, John. "The Nature and Origins of Mass Opinion." Public Opinion Quarterly 58, no. 4 (1994): 633.

Zaller, John, and Dennis Chu. “Government's Little Helper: U.S. Press Coverage of Foreign Policy Crises, 1945-1991.” Political Communication 13 (1996): 385-405. 